\title{
Horizontal spatial and temporal distribution patterns of nearshore larval fish assemblages at a temperate rocky shore
}

\author{
Rita Borges ${ }^{\mathrm{a}}$, Radhouan Ben-Hamadou ${ }^{\mathrm{b}}$, M. Alexandra Chícharo ${ }^{\mathrm{b}}$, \\ Pedro Ré ${ }^{\mathrm{c}}$, Emanuel J. Gonçalves ${ }^{\mathrm{a}, *}$ \\ ${ }^{a}$ Eco-Ethology Research Unit, Instituto Superior de Psicologia Aplicada, R. Jardim do Tabaco 34, 1149-041 Lisboa, Portugal \\ ${ }^{\mathrm{b}}$ CCMAR, FCMA, Universidade do Algarve, Campus de Gambelas, 8005-139 Faro, Portugal \\ ${ }^{\mathrm{c}}$ Faculdade de Ciências da Universidade de Lisboa, Departamento de Biologia Animal, Campo Grande, 1749-016 Lisboa, Portugal
}

Received 14 May 2006; accepted 9 August 2006

Available online 18 October 2006

\begin{abstract}
There have been no previous studies of the composition of nearshore larval fish assemblages along the coast of Portugal. We aimed to describe the composition and horizontal distribution patterns of larval fish assemblages and their temporal dynamics near a rocky reef at depths shallower than $13 \mathrm{~m}$ (inshore) and at two miles $(3.70 \mathrm{~km}$ ) from shore (offshore), as well as along transects perpendicular to the shoreline, from the reef to 10 miles offshore $(18.52 \mathrm{~km})$. Samples were taken using 5 min sub-surface trawls at the rocky shore of the Arrábida Marine Park (W Portugal). A total of 1021 larvae were collected, belonging to 61 taxa inshore and to 29 taxa offshore. Along transects, 626 larvae of 52 taxa were collected. Most larvae belonged to coastal species associated with rocky reefs. Total larval abundance and diversity were higher from May to July, which is consistent with the spawning activity of adults. Diversity and total larval abundance decreased significantly with increasing distance from shore, both in the inshore/offshore comparison and in the transects, where this decrease was evident at a very small spatial scale (within the first mile from the reef). Species assemblages differed in the pattern of distribution, with most species clearly associated to the extreme nearshore. The distribution patterns obtained were independent of the spawning mode of species. Results are discussed in the light of the possible physical mechanisms that can potentially act at the Arrábida Marine Park to facilitate larvae retention and the role of larval behaviour.
\end{abstract}

(C) 2006 Elsevier Ltd. All rights reserved.

Keywords: larval fishes; horizontal distribution; retention; nearshore; temperate reefs

\section{Introduction}

Recruitment of reef fish populations is variable and can be strongly affected by patterns of larval supply (Victor, 1986; Doherty, 1991; Milicich et al., 1992; Meekan et al., 1993; Sponaugle and Cowen, 1996; Jenkins et al., 1998; Valles et al., 2001; Cowen, 2002; Leis and McCormick, 2002). The degree of larval dispersal influences connectivity between reef fish populations affecting their dynamics, given that a lower dispersal can enhance local larval supply and result

\footnotetext{
* Corresponding author.

E-mail address: emanuel@ispa.pt (E.J. Gonçalves).
}

in a higher level of self-recruitment (Cowen, 2002; Leis, 2002; Mora and Sale, 2002; Sponaugle et al., 2002; Swearer et al., 2002; Irisson et al., 2004; Sale, 2004). Populations can thus be more open or closed, depending on the scale considered (Caley et al., 1996; Cowen, 2002; Leis, 2002). To best understand this issue, which can have a strong impact on the management of fisheries and marine protected areas (Planes et al., 2000; Stobutzki, 2001; Caselle et al., 2003; Leis, 2003; Shanks et al., 2003; Miller and Shanks, 2004), it is necessary to investigate the patterns of larval distribution and their temporal variation (Warner and Cowen, 2002). Given that local scale processes may affect dispersal of reef fish larvae (Pineda, 2000; Cowen, 2002; Sponaugle et al., 2002; Largier, 2003), small-scale studies on larval spatial 
distributions can give important information about possible retention mechanisms near the adults' habitat (Cowen, 2002). Moreover, the study of small-scale temporal patterns of variation in the composition of assemblages can be used to determine duration of breeding seasons and dynamics of recruitment patterns of coastal species.

There is a growing body of evidence showing that some reef fish populations may have a degree of self-recruitment higher than previously expected, leading to more closed populations at ecologically relevant scales (Jones et al., 1999, 2005; Swearer et al., 1999; Leis and McCormick, 2002; Swearer et al., 2002; Taylor and Hellberg, 2003; Miller and Shanks, 2004; Paris and Cowen, 2004). Reef fish larvae must find a suitable habitat to settle after the end of the pelagic phase and remaining close to reefs may be advantageous (Leis, 1991; Swearer et al., 1999).

Recent in situ and laboratory studies have shown that fish larvae in coral reef systems can have strong swimming capabilities (e.g. Leis and Stobutzki, 1999; Fisher and Bellwood, 2002, 2003; Fisher, 2005), but also in temperate waters (Dudley et al., 2000; Leis et al., 2006). These larvae seem to react to different environmental factors (reviewed by Montgomery et al., 2001; Kingsford et al., 2002; Myrberg and Fuiman, 2002), including reef sounds (Stobutzki and Bellwood, 1998; Tolimieri et al., 2000, 2004; Leis et al., 2002, 2003; Simpson et al., 2004, 2005; Leis and Lockett, 2005) and chemical cues (Atema et al., 2002). Swimming capabilities can allow larvae to regulate their horizontal and vertical position in the water column, potentially affecting their retention near-reefs (Fisher, 2005; Leis et al., 2006). In fact, the ability of larval fishes to vertically migrate is well documented for offshore waters (reviewed by Neilson and Perry, 1990), and for the estuarine environment (reviewed by Norcross and Shaw, 1984; Boehlert and Mundy, 1988). Vertical migrations seem to allow larvae to actively select the appropriate currents for transport (Paris and Cowen, 2004). Larval behaviour and other biological factors such as planktonic larval durations, size at hatching, and spawning mode of adults, can interact with physical factors, affecting dispersal in nearshore environments (Cowen and Sponaugle, 1997; Sponaugle and Cowen, 1997). For instance, particular oceanographic features such as the interaction between tidal flow and bottom topography, fronts, eddies and internal bores, can facilitate retention of planktonic organisms (Pineda, 2000; Cowen, 2002; Largier, 2003).

Several studies have found cross-shelf gradients in the structure of larval assemblages (e.g. Gray, 1993; John and Ré, 1993). However most of these studies were performed at large spatial scales which miss smaller patterns that may be relevant to population dynamics. Small-scale spatial and temporal patterns in the composition of larval assemblages have been a focus of attention in coral reefs (see reviews by Leis, 1991; Cowen, 2002; Leis and McCormick, 2002). If larval retention occurs near-reefs, the expected horizontal patterns of distribution will be a decrease of reef fish larval abundance with increasing distances from shore, while species that spawn offshore should show the opposite trend. This was clearly described by Leis and Miller (1976) in Hawaii who found that the patterns of larval distribution were visibly associated with the mode of spawning. The inshore assemblage was mainly composed by reef fish larvae hatching from benthic eggs, while offshore larvae were mainly from species which lay pelagic eggs. Several other studies showed evidence of reef fish larvae being retained nearshore (reviews by Cowen, 2002; Leis and McCormick, 2002; Swearer et al., 2002; Sponaugle et al., 2003; Paris and Cowen, 2004). However, the patterns obtained in several of these studies were found to be quite variable and species specific (Cowen, 2002).

In temperate rocky reefs, studies of nearshore larval fish assemblages' composition and dynamics are scarce. However, differences between the composition of those assemblages and the ones found offshore have been described (Marliave, 1986; Kingsford and Choat, 1989; Suthers and Frank, 1991; Brogan, 1994; Tilney et al., 1996; Sabatés et al., 2003). Some of these studies suggest that larvae from inshore species spawning demersal eggs dominate the shallow water assemblages, being more abundant than in offshore waters (e.g. Marliave, 1986; Suthers and Frank, 1991), which indicates that nearshore larval retention is also possible in temperate environments, either being locally produced or transported from other reefs by alongshore currents.

There are no previous studies on the composition of nearshore larval assemblages along the Portuguese coast. A highly diverse adult reef fish community has been documented in the Arrábida Marine Park (Henriques et al., 1999; Gonçalves et al., 2003), but nothing is known about the distribution of their larval stages and recruitment processes. With the general goal of studying larval dispersal patterns of reef fishes living at the Arrábida Marine Park, in this work we investigate: (1) the composition and temporal patterns of larval assemblages inshore (at the extreme nearshore) and offshore (at two miles from the reef); and (2) the spatial patterns of distribution of larval assemblages with increasing distance from the reef.

\section{Materials and methods}

The study area is located on the west Portuguese shore, at the Arrábida Marine Park $\left(8^{\circ} 58^{\prime} 40^{\prime \prime}-9^{\circ} 04^{\prime} 20^{\prime \prime} \mathrm{W}\right.$ and $38^{\circ} 26^{\prime}-38^{\circ} 27^{\prime} \mathrm{N}$ ). This area faces south (Fig. 1) and is protected from the prevailing north and north-west winds by the adjacent mountain chain of Arrábida. The rocky subtidal habitat is very shallow (maximum depth about $13 \mathrm{~m}$ ) and heterogeneous due to different sized boulders resulting from erosion of the calcareous cliffs. The rocky subtidal extends offshore for only some tens of meters. Calm conditions exist almost all year round and wave action is negligible, allowing sampling at the very nearshore $(<50 \mathrm{~m}$ from shore). Although local nearshore hydrodynamics is poorly understood, alongshore currents prevail at the study site. The flow of the nearby Sado River is negligible during the spring-summer period (Martins et al., 2001, 2002). South from the estuary, sandy shores extend for several miles and off this coast, southerly to the Arrábida Marine Park, there is the Setúbal Canyon.

A $350-\mu \mathrm{m}$ mesh plankton net with a $0.30 \mathrm{~m}$ mouth diameter and a 1:5 mouth diameter: net length ratio was towed by a small 


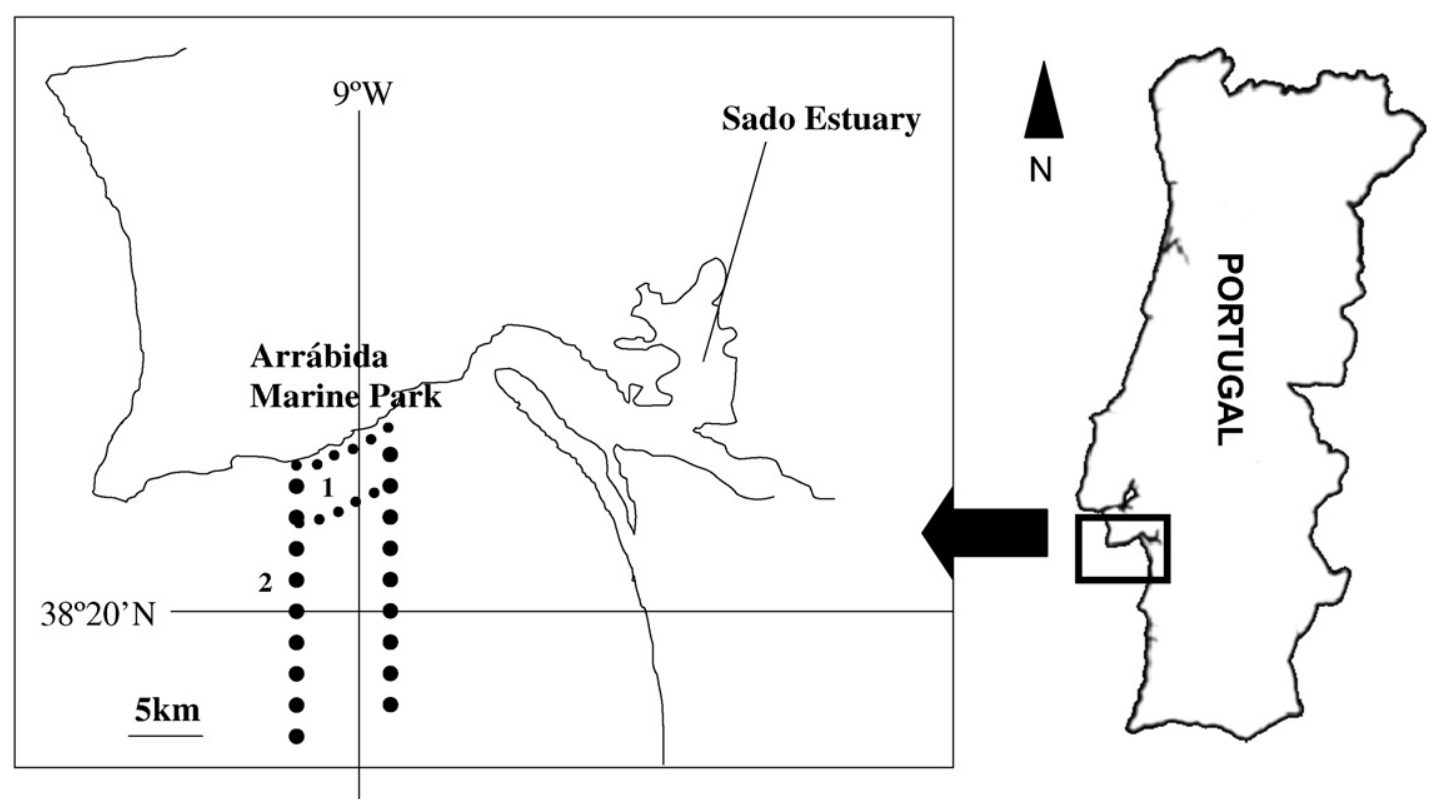

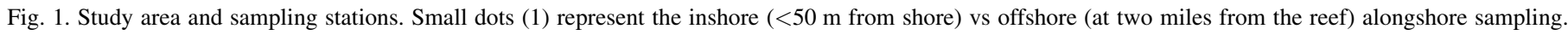
Larger dots (2) represent the two outer perpendicular transects (the others were performed in between these two lines).

$4.6 \mathrm{~m}$ semi-rigid inflatable boat at a distance of $20 \mathrm{~m}$ from the boat, and at a speed of approximately 1.5 knots. One Hydrobios flowmeter was attached to the net to estimate the sampled volumes. Filtered volumes, and number of larvae caught are shown in Table 1. All samples were taken during the day between $10 \mathrm{~h} 30 \mathrm{~min}$ and $17 \mathrm{~h} 15 \mathrm{~min}$, at all tidal phases.

Samples were preserved in $4 \%$ seawater formalin buffered with sodium borate, for at least one month before larvae were

Table 1

Sampling periods, volumes filtered and number of larvae caught in the inshore/offshore sampling and in the transects perpendicular to shore

\begin{tabular}{|c|c|c|c|c|c|c|c|c|}
\hline \multirow[t]{2}{*}{ Distance } & \multirow[t]{2}{*}{ Month } & & \multirow[t]{2}{*}{$N$} & \multicolumn{2}{|c|}{ Volume $\left(\mathrm{m}^{3}\right)$} & \multicolumn{2}{|c|}{$\mathrm{N}^{\circ}$ larvae } & \multirow[t]{2}{*}{ Total } \\
\hline & & & & Mean & SD & Mean & $\mathrm{SD}$ & \\
\hline \multicolumn{9}{|l|}{ Inshore/offshore } \\
\hline \multirow{6}{*}{$\begin{array}{l}\text { Inshore } \\
\qquad(<50 \mathrm{~m} \text { from the reef })\end{array}$} & May & 03 May & 15 & 28.96 & 2.39 & 16.80 & 7.66 & 252 \\
\hline & Jun & 31 May;08 Jun & 15 & 29.87 & 7.71 & 9.93 & 5.04 & 149 \\
\hline & Jul & $11 \mathrm{Jul}$ & 15 & 26.87 & 5.43 & 21.33 & 10.24 & 320 \\
\hline & Aug & 01 Aug & 15 & 28.73 & 3.52 & 5.13 & 3.44 & 77 \\
\hline & Sep & 04; $06 \mathrm{Sep}$ & 29 & 28.90 & 3.20 & 0.34 & 0.72 & 10 \\
\hline & Oct & $10 ; 18$ Oct & 15 & 29.66 & 5.04 & 2.33 & 2.06 & 35 \\
\hline \multirow{6}{*}{$\begin{array}{l}\text { Offshore } \\
\text { (two miles from the reef) }\end{array}$} & May & 03 May & 15 & 31.73 & 3.14 & 2.93 & 2.28 & 44 \\
\hline & Jun & 31 May;08 Jun & 15 & 29.86 & 2.86 & 3.87 & 2.67 & 58 \\
\hline & Jul & $11 \mathrm{Jul}$ & 15 & 23.72 & 2.63 & 0.47 & 0.74 & 7 \\
\hline & Aug & $01 \mathrm{Aug}$ & 14 & 30.42 & 3.41 & 2.86 & 3.23 & 40 \\
\hline & Sep & 04; 06 Sep & 30 & 33.13 & 2.06 & 0.00 & & 0 \\
\hline & Oct & $10 ; 18$ Oct & 11 & 23.80 & 9.79 & 2.64 & 1.57 & 29 \\
\hline Total & & & 204 & 29.22 & 5.05 & 5.00 & 7.59 & 1021 \\
\hline \multicolumn{9}{|l|}{ Perpendicular transects } \\
\hline & Near-reef & & 30 & 27.80 & 4.59 & 13.23 & 11.14 & 397 \\
\hline & 1st mile & & 17 & 30.19 & 5.75 & 6.00 & 5.57 & 102 \\
\hline & 2nd mile & & 17 & 29.32 & 4.21 & 2.59 & 2.21 & 44 \\
\hline & 3rd mile & & 18 & 28.41 & 5.24 & 0.94 & 0.73 & 17 \\
\hline & 4th mile & & 17 & 30.43 & 2.85 & 0.59 & 1.00 & 10 \\
\hline & 5th mile & & 17 & 29.96 & 3.50 & 0.59 & 0.87 & 10 \\
\hline & 6th mile & & 17 & 31.66 & 3.85 & 0.47 & 0.62 & 8 \\
\hline & 7th mile & & 17 & 31.14 & 2.54 & 0.76 & 0.90 & 13 \\
\hline & 8th mile & & 17 & 30.37 & 3.38 & 0.47 & 1.01 & 8 \\
\hline & 9th mile & & 17 & 30.62 & 3.01 & 0.41 & 0.94 & 7 \\
\hline & 10th mile & & 16 & 31.49 & 3.24 & 0.63 & 1.31 & 10 \\
\hline Total & & & 200 & 29.96 & 4.12 & 3.13 & 6.48 & 626 \\
\hline
\end{tabular}


sorted and identified to the lowest possible taxonomic level under a stereomicroscope equipped with a digital camera. Identifications were based on Bardi and Friedländer (19311956), Russell (1976), Moser (1984), Ré (1999), and the remaining available literature. The developmental stage of each individual was classified as: pre-flexion, incomplete flexion or complete flexion, according to Leis and CarsonEwart (2000). Body length (BL) was measured to the nearest $0.01 \mathrm{~mm}$, under a stereomicroscope. This measurement corresponded to the length of the notochord in pre-flexion or incomplete flexion stage larvae and to standard length in post-flexion larvae. All larval stages from hatching were considered, including yolk-sac larvae. For sardine larvae, only individuals bigger than $2.75 \mathrm{~mm}$ BL were considered as larvae, since hatching occurs at 3.0-4.0 mm (Ré, 1999). Smaller individuals were considered as free embryos. For the other species with larvae hatching from pelagic eggs this distinction was not possible and every individual caught was considered as a larva.

\subsection{Inshoreloffshore comparison}

\subsubsection{Sampling procedure}

All samples were collected between May and October 2000 (Table 1). This period corresponds to the breeding season of most reef species occurring in the study area (Henriques et al., 1999). Monthly sampling was performed with at least 11 samples taken each month in the extreme nearshore (less than $50 \mathrm{~m}$ from shore) over rocky reefs (inshore samples) and at two miles from the reef (offshore samples). Samples were collected through $5 \mathrm{~min}$ sub-superficial tows (1 $\mathrm{m} \mathrm{depth}$ ), parallel to the rocky shore (see Fig. 1).

\subsubsection{Data analysis}

An overview of the overall analysis is shown in Fig. 2. Detailed procedures are described below.

2.1.2.1. Total abundance and diversity. Larval abundance is expressed as the number of larvae per $1000 \mathrm{~m}^{3}$. Two biodiversity indices were calculated for each sample: the Shannon Diversity Index $\left(H^{\prime}\right)$ using the natural logarithm in its formulation; and the Average Taxonomic Distinctness Index (Delta*) which reflects the taxonomic spread of species among samples (Clarke and Warwick, 2001). Delta* is based in the taxonomic distances between every pair of individuals. High Delta* values $($ maximum $=100)$ reflect high taxonomic diversity in the assemblage (Clarke and Warwick, 2001). Four taxonomic levels were used, from species to order, assuming equal step-lengths between each taxonomic level. Mean values and standard deviations of total abundance and of diversity indices were calculated for each month for the inshore and offshore samples.

In order to investigate the spatial and temporal patterns of variation in $H^{\prime}$, possible interactions between months and distance from the reef (inshore vs offshore samples) were tested using a factorial ANOVA, considering months and distance from the reef as factors. September was excluded from this comparison since no larvae were caught offshore (Table 1). The Newman-Keuls test was used for post hoc comparisons. Total abundance and Delta* at the inshore and offshore samples were tested with a Kruskal-Wallis ANOVA given that the homoscedascity assumption was violated even after $\log (x+1)$ transformation of the data. Post hoc comparisons were performed with the Dunn's test. Using the same criteria, Student's- $t$ or Mann-Whitney $U$ tests were used for the comparisons between inshore and offshore samples for each month.

2.1.2.2. Assemblage structure. Samples were classified in 11 groups at the inshore and offshore samples, corresponding to each month. Abundance of each species in each sample was used to calculate a triangular matrix of Bray-Curtis similarities after a $\log (x+1)$ transformation. Non-identifiable larvae totalled $13.5 \%$, all in pre-flexion stage, and were not considered in the analysis. Differences in assemblage structure were tested with a one-way analysis of similarities (ANOSIM). High $R$ values indicate differences between groups. The significance level is given by referring the $R$ value to its permutation distribution (Clarke and Warwick, 2001). Similarity percentages analysis (SIMPER) was used to determine the species contribution to each group, assuming a cut off at $95 \%$.

\subsection{Spatial comparison of transects}

\subsubsection{Sampling procedure}

Sampling was made along 17 parallel transects, 0.3 miles $(0.62 \mathrm{~km})$ apart (Fig. 1), between 11 July and 1 August 2000. We chose this period since July is the summer month with the highest larval abundance (see Section 3.1.1). In each transect, one sample tow was performed within each mile from the reef to the 10th mile (Table 1). Each transect was performed along a different longitude, covering the area of the Arrábida Marine Park between the two lines shown in Fig. 1. Tows were performed in both directions, towards and away from the reef. Samples collected in July and August at the nearshore for the inshore/offshore comparison were used as the near-reef sampling point for this comparison. The reason for this was the fact that larval density decreases abruptly during the first mile and therefore a small-scale analysis seemed appropriate (see Section 3.2.1). The near-reef sampling point differed from the others since sampling was done alongshore instead of perpendicularly to the shore line.

\subsubsection{Data analysis}

2.2.2.1. Total abundance and diversity. The same abundance and diversity criteria defined for the inshore/offshore comparison were used. To evaluate grouping patterns between transect stations, a Q-mode clustering (Legendre and Legendre, 1998) with contiguity constraint for each transect was calculated, based on the Bray-Curtis similarity index, and using total abundances. Since the data are multivariate we used a pooled variance-covariance matrix to compute overall 


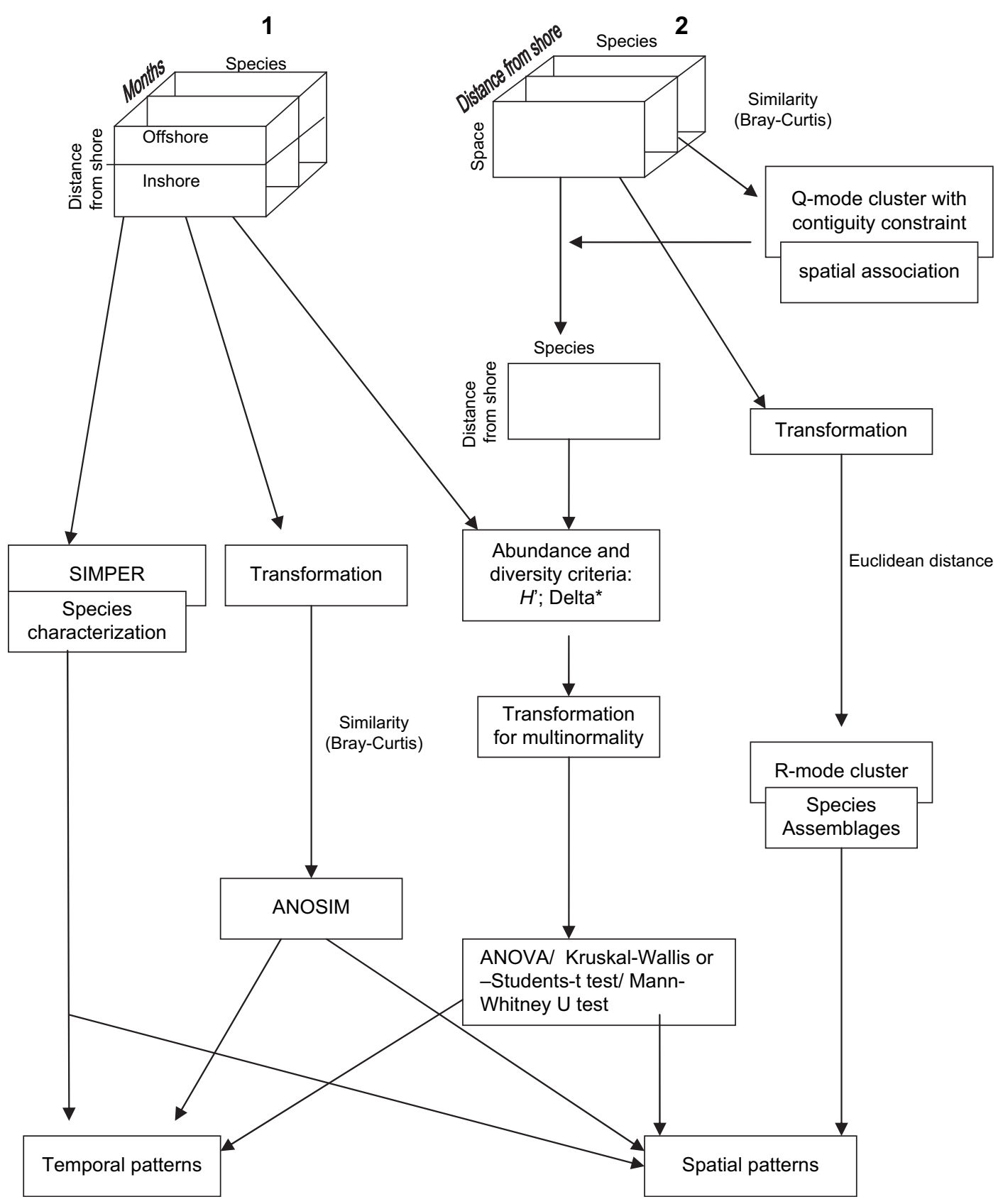

Fig. 2. Summary of the statistical analysis used in the inshore/offshore comparison (1) and in the spatial analysis of transects (2).

variances. The Pillai-Bartlett trace criterion was applied, because of its robustness vs the Wilk's lambda test (Olson, 1976). Diversity indices were tested across the cluster groups defined with a one-way ANOVA and total abundance was tested across the groups of miles with a Kruskal-Wallis ANOVA, since homoscedascity assumptions were not met even after a $\log (x+1)$ transformation. For post hoc comparisons, the Newman-Keuls and the Dunn's test were used, respectively. Contour mapping was utilised to present results of the spatial patterns of total abundance and diversity, excluding four transects where there was no sampling at the near-reef and one transect without sampling at the 10th mile. The resulting matrix had 11 stations (from the near-reef to 10 miles) $\times 12$ transects. The SURFER software was used to display the maps. Interpolation was made with the Kriging method (Legendre and Legendre, 1998).

2.2.2.2. Assemblage structure. The species assemblages were defined using an R-mode clustering (after Legendre and Legendre, 1998), based on euclidean distances and after normalization of the abundance values. Overall variances were also calculated with the Pillai-Bartlett trace criterion. Total larval abundance for each group of species defined by the cluster analysis was also mapped using the SURFER Software. For those species belonging to the first group (near-reef to the 2nd mile), small-scale patterns of distribution were investigated by comparing the first three stations within the group (near-reef, 1st mile and 2nd mile) with 
a Kruskal-Wallis ANOVA or Mann-Whitney $U$ test, since parametric assumptions were violated even after $\log (x+1)$ transformation.

\section{Results}

\subsection{Inshoreloffshore comparison}

A total of 61 taxa were identified. From these, 57 taxa occurred inshore, comprising 27 families with 35 genera and at least 40 recognizable species. Offshore, the number of taxa was lower (29) belonging to 17 families with 19 genera and at least 15 identified species (Table 2).

\subsubsection{Diversity and abundance}

The Shannon diversity index $\left(H^{\prime}\right)$ revealed a temporal $(F \quad(4, \quad N=121)=6.99, \quad P<0.001)$ and spatial $(F \quad(1$, $N=121)=56.22, P<0.001)$ pattern of variation with a significant interaction $(F(4, N=121)=6.46, P<0.001)$ between these factors (Fig. 3a). A significantly higher diversity was found in inshore samples in May and July than in August $(P<0.05)$ and in May, June and July than in October $(P<0.001)$. Offshore, the only significant fluctuation was an increase in diversity from July to August $(P<0.05)$. In May, June and July diversity was significantly higher $(P<0.001)$ inshore than offshore (Fig. 3a).

The average taxonomic index (Delta*) had a similar temporal pattern of variation (Fig. 3b). However, no significant variation was found offshore $(H(4, N=50)=4.74$, n.s. $)$ while inshore significant temporal differences occurred $(H \quad 5$, $N=78)=16.77, P<0.01)$ with a decrease in taxonomic diversity from May to September $(P<0.001)$ and from August to September $(P<0.05)$. Delta* was also always higher inshore than offshore with significant differences in May and July (Fig. 3b, Table 3).

Abundance changed significantly through time, both inshore $(H(5, N=104)=86.58, P<0.01)$ and offshore $(H$ $(5, N=100)=58.88, P<0.01)$. Inshore samples had higher values of abundance in May, June and July (when they reached the maximum) (Fig. 4). From August onwards a significant decrease occurred, with significantly lower values than in July $(P<0.05)$ and higher than in September $(P<0.01)$. September and October samples also differed significantly from those of May, June and July $(P<0.001)$, except for June vs October $(P<0.05)$. Offshore, the pattern was somewhat different. June was the month with the highest abundance, and a significant decrease occurred from June to July $(P<0.01)$ and again from August to September $(P<0.01)$, followed by a significant increase in October $(P<0.001)$. September differed significantly from May and June $(P<0.001)$ and October presented higher abundances than July $(P<0.05)$. From May to August, abundance was significantly higher inshore than offshore (Fig. 4, Table 3).

\subsubsection{Assemblage structure}

Considering the similarities between the 11 groups (each group being constituted by the samples of each month at each distance), global $R$ was low $(R=0.39, P<0.001)$. Nevertheless, some differences were detected in the pairwise comparisons. Inshore, $R$ values close to 0.5 were found when comparing July with the preceding months (May vs July: $\quad R=0.49, \quad P<0.001$; June vs July: $R=0.44$, $P<0.001)$. Stronger differences were detected when contrasting the May, June and July assemblages with those of September and October, with $R$ values between 0.48 (June-September, $P<0.001$ ) and 0.71 (July-October, $P<0.001)$. Offshore, the highest $R$ values were obtained in the June-July $(R=0.47, \quad P<0.01)$ and July-August ( $R=0.45, P<0.01)$ comparisons. Within each month, July was the only with a clear spatial structure, with a strong difference between the inshore and offshore assemblages $(R=0.92$, $P<0.01)$.

Table 4 lists the species that contributed more to explain the similarities between samples of the same group, from the SIMPER results. Within each group, the average similarity between samples was generally low. Nonetheless, these results are informative in what concerns the composition of the assemblages. Inshore, the number of contributing taxa was always higher than offshore for each month. Species whose adults live and spawn nearshore, like Tripterygion delaisi, Coryphoblennius galerita, Parablennius gattorugine or Symphodus spp., contributed to explain similarities only among inshore samples. Parablennius pilicornis was the main species explaining similarities between May samples at both distances and also contributed to similarities among inshore samples in June, July and September. In June, the only two species (Sparidae sp1 and Gobius niger type) contributing to similarities among offshore samples were also present inshore with higher abundances. July presented the highest similarities among inshore samples and the lowest at offshore samples, explained by only one species (Serranus cabrilla).

\subsubsection{Developmental stage}

For the most abundant taxa (more than 20 individuals) BL and larval developmental stage are presented in Table 5. At both inshore and offshore locations most larvae were small and undeveloped (pre-flexion stage). A few species, however, presented more developed larvae. Inshore, $33.3 \%$ of Gobius niger type larvae were in the incomplete flexion stage and $6.7 \%$ in the post-flexion stage, while offshore incomplete flexion stage larvae made up to $36.8 \%$ of the species. In Coryphoblennius galerita, only one incomplete flexion and one post-flexion larva occurred inshore and in Parablennius pilicornis only one post-flexion stage larva was collected both inshore and offshore. Larvae of species hatching from pelagic eggs, like Diplodus spp., Sardina pilchardus and Serranus spp., were present inshore at incomplete flexion stage with occurrences of $21.7 \%, 6.9 \%$ and $1.6 \%$, respectively.

\subsection{Spatial comparison of transects}

An evaluation of the grouping patterns of stations within transects showed a significant spatial segregation of stations in four distinct groups (Pillai's trace $=0.735, P<0.01$ ) 
Table 2

Species composition and abundance (expressed as the mean number of larvae/1000 $\left.\mathrm{m}^{3}\right)$ of the inshore $(<50 \mathrm{~m}$ from the reef) and offshore (at two miles from the reef) assemblages. $\mathrm{SD}=$ standard deviation

\begin{tabular}{|c|c|c|c|c|c|}
\hline \multirow[t]{2}{*}{ Family } & \multirow[t]{2}{*}{ Species } & \multicolumn{2}{|c|}{ Inshore } & \multicolumn{2}{|c|}{ Offshore } \\
\hline & & Mean & SD & Mean & SD \\
\hline \multirow[t]{3}{*}{ Ammodytidae } & Ammodytes tobianus & & & 0.97 & 9.67 \\
\hline & Ammodytidae n.i. & & & 1.05 & 7.45 \\
\hline & Gymnammodytes semisquamatus & 0.97 & 5.65 & & \\
\hline Atherinidae & Atherina presbyter & 1.77 & 7.97 & 0.32 & 3.25 \\
\hline Belonidae & Belone spp. & 2.05 & 10.86 & 2.70 & 12.69 \\
\hline \multirow[t]{3}{*}{ Blenniidae } & Coryphoblennius galerita & 12.28 & 27.61 & & \\
\hline & Parablennius gattorugine & 3.27 & 15.71 & & \\
\hline & Parablennius pilicornis & 62.52 & 131.00 & 6.38 & 22.15 \\
\hline Bothidae & Arnoglossus spp. & 5.44 & 18.63 & 0.61 & 4.31 \\
\hline Callionymidae & Callionymus spp. & 3.30 & 12.13 & 0.32 & 3.25 \\
\hline Caproidae & Capros aper & 0.83 & 6.10 & 0.45 & 4.53 \\
\hline \multirow[t]{4}{*}{ Carangidae } & Carangidae spx & 0.41 & 4.18 & & \\
\hline & Trachurus mediterraneus & 0.37 & 3.80 & & \\
\hline & Trachurus spp. & 0.34 & 3.46 & 0.28 & 2.85 \\
\hline & Trachurus trachurus & 1.74 & 7.82 & & \\
\hline Clupeidae & Sardina pilchardus & 28.86 & 61.13 & 1.45 & 7.21 \\
\hline Engraulidae & Engraulis encrasicolus & 1.03 & 6.03 & 0.51 & 5.08 \\
\hline Gobiesocidae & Lepadogaster lepadogaster & 0.34 & 3.44 & & \\
\hline \multirow[t]{8}{*}{ Gobiidae } & Gobiidae A & 0.29 & 2.92 & & \\
\hline & Gobiidae n.i. & 1.35 & 6.81 & 0.66 & 4.67 \\
\hline & Gobius niger type & 9.99 & 41.28 & 6.28 & 17.96 \\
\hline & Gobius spp. & 0.29 & 2.91 & 0.29 & 2.92 \\
\hline & Gobius cruentatus type & 0.33 & 0.03 & & \\
\hline & Gobiusculus flavescens & 0.37 & 3.74 & & \\
\hline & Pomatoschistus pictus & 3.36 & 10.53 & 0.32 & 3.24 \\
\hline & Pomatoschistus spp. & 0.86 & 6.27 & & \\
\hline \multirow[t]{5}{*}{ Labridae } & Coris julis & 8.29 & 24.18 & 1.54 & 7.84 \\
\hline & Ctenolabrus rupestris & 1.04 & 6.05 & & \\
\hline & Symphodus melops type & 3.21 & 11.71 & 0.42 & 4.20 \\
\hline & Symphodus roissali & 5.64 & 18.47 & & \\
\hline & Symphodus spp. & 0.33 & 3.32 & & \\
\hline Lotidae & Gaidropsarus mediterraneus & 0.35 & 3.61 & & \\
\hline Macrorhamphosidae & Macrorhamphosus scolopax & 0.28 & 2.89 & & \\
\hline \multirow[t]{2}{*}{ Mugilidae } & Liza ramada & 1.23 & 7.25 & & \\
\hline & Mugilidae n.i. & 2.53 & 12.10 & 4.73 & 19.28 \\
\hline Mullidae & Mullus surmuletus & 4.12 & 16.75 & 1.41 & 6.94 \\
\hline Myctophidae & Myctophidae n.i. & 0.29 & 2.94 & & \\
\hline Scombridae & Scomber japonicus & 0.29 & 2.91 & & \\
\hline Scorpaenidae & Scorpaena porcus & 0.37 & 3.74 & & \\
\hline \multirow[t]{3}{*}{ Serranidae } & Serranus atricauda & 0.32 & 3.27 & & \\
\hline & Serranus cabrilla & 0.30 & 3.04 & 1.01 & 7.12 \\
\hline & Serranus spp. & 24.26 & 65.22 & 1.61 & 7.08 \\
\hline \multirow[t]{4}{*}{ Soleidae } & Solea lascaris & 0.36 & 3.65 & & \\
\hline & Solea spp. & 0.37 & 3.74 & 0.32 & 3.25 \\
\hline & Solea vulgaris & 0.29 & 2.94 & & \\
\hline & Soleidae n.i. & 0.73 & 5.28 & 0.30 & 3.00 \\
\hline \multirow[t]{9}{*}{ Sparidae } & Boops boops & 2.69 & 18.06 & & \\
\hline & Diplodus spp. & 7.49 & 24.45 & 1.92 & 9.88 \\
\hline & Pagellus sp1 & 5.51 & 14.64 & 0.67 & 4.68 \\
\hline & Pagellus spp. & & & 0.66 & 4.72 \\
\hline & Sparidae n.i. & 3.94 & 12.52 & 1.75 & 9.49 \\
\hline & Sparidae sp1 & 27.78 & 49.19 & 5.62 & 18.01 \\
\hline & Sparidae $\mathrm{sp} 2$ & 4.11 & 17.73 & & \\
\hline & Sparidae sp3 & & & 2.54 & 11.69 \\
\hline & Spondyliosoma cantharus & 0.35 & 3.56 & & \\
\hline \multirow[t]{2}{*}{ Syngnathidae } & Entelurus aequoreus & 0.34 & 3.50 & & \\
\hline & Hippocampus ramulosus & 0.75 & 5.41 & & \\
\hline Trachinidae & Echiichthys vipera & 0.38 & 3.87 & & \\
\hline & Trachinus draco & 2.44 & 12.22 & & \\
\hline Triglidae & Triglidae n.i. & 0.88 & 6.41 & & \\
\hline Tripterygiidae & Tripterygion delaisi & 7.71 & 27.37 & & \\
\hline n.i. & n.i. & 32.49 & 54.74 & 14.89 & 33.44 \\
\hline
\end{tabular}



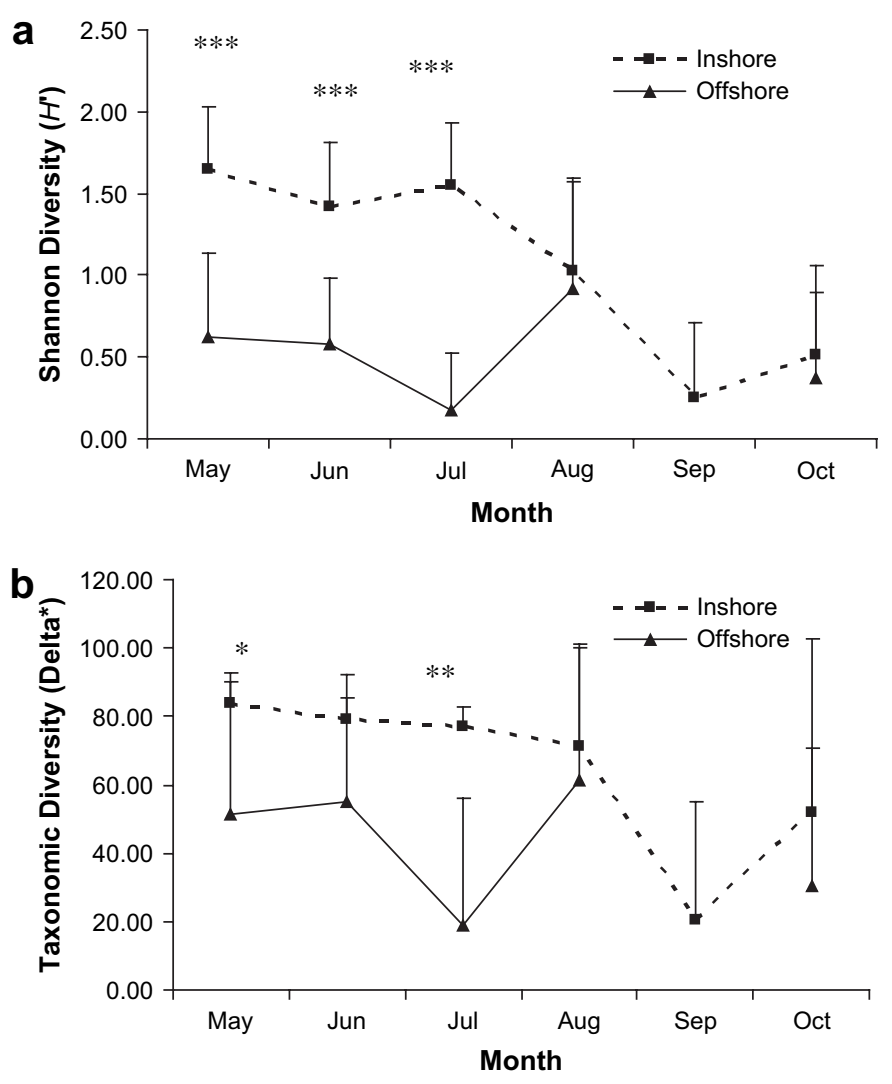

Fig. 3. (a) Temporal variation of mean Shannon Diversity Index $\left(H^{\prime}\right)$ at both distances from shore. ${ }^{* * *}$ represent significant differences (at $P<0.001$ ) between the inshore and offshore samples, for each month. Error bars are standard deviations. (b) Temporal variation of mean Taxonomic Diversity Index $\left(\right.$ Delta $\left.^{*}\right)$ at both distances from shore. *, ** represent significant differences between inshore and offshore samples, for each month, at $P<0.05$ and $P<0.01$, respectively (statistics results shown in Table 3). Error bars are standard deviations.

(Fig. 5). Group 1 contained stations near-reef to 2 miles distant with the near-reef separated from miles 1 and 2 . Group 2 gathered stations 3-6 miles and Group 3 stations 7-9 miles. The fourth group contained only the station at 10 miles. Overall, 51

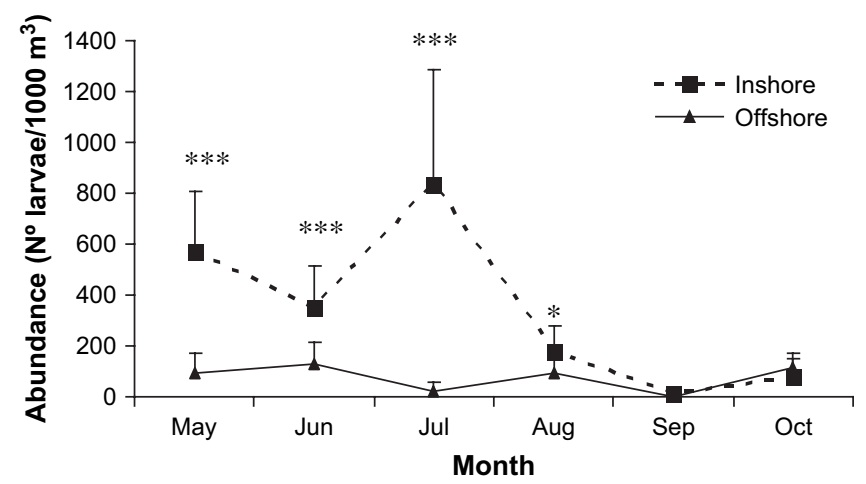

Fig. 4. Temporal variation of mean larval abundance at both distances from shore. $*$, *** represent significant differences between inshore and offshore samples, for each month, at $P<0.05$ and at $P<0.001$, respectively (statistics results shown in Table 3 ); error bars are standard deviations. taxa were identified, comprising 22 families with 31 genera and 33 species.

\subsubsection{Diversity and abundance}

Spatial patterns of diversity found along transects are graphically represented in Fig. 6. Diversity differed with increasing distance from the reef $\left(H^{\prime}: F(3, N=108)=25.38\right.$, $P<0.001$; Delta*: $F(3, N=108)=16.06, P<0.001)$ being significantly higher in the first group of miles when compared with the other groups of stations for both $H^{\prime}(P<0.001)$ and Delta* $^{*}(P<0.01)$. Larval abundance followed a similar trend with maximum values occurring near-reef and decreasing with increasing distance from the reef (Fig. 7a). Total abundance also varied $(H(3, N=200)=94.42, P<0.001)$, being significantly higher (at $P<0.001$ ) in Group 1 when compared to the other three groups.

\subsubsection{Assemblage structure and composition}

R-mode clustering of larval composition and density defined four distinct assemblages of species (Pillai's trace $=0.53, P<0.05)$. Species composition and mean densities for each group of stations defined above are expressed in Table 6. For each group of species, spatial variation along transects is shown in Fig. 7.

The first assemblage was composed of species that appeared only in Group 1 of stations (near-reef to the 2 nd mile) (e.g. Ctenolabrus rupestris, Boops boops and Pomatoschistus pictus) and by some species that, although having higher abundances near the reef, were also present off the reef, like Sardina pilchardus and Symphodus melops type (Table 6, Fig. 7 b). The second assemblage, contained species that were present within the first two groups of miles (e.g. Parablennius gattorugine) or exclusively near the reef (Table 6, Fig. 7c). Species from the third assemblage presented a broader range of distribution (Table 6, Fig. 7d). For example, Mugilidae n.i. and Gobius niger type were present in all groups. Gobius niger type was more abundant in the first and third groups of miles and Mugilidae n.i. had higher abundances in the second group. Mullus surmuletus was the only species with a higher abundance away from the reef (Table 6). Finally, the fourth assemblage (Table 6, Fig. 7e) comprised $45 \%$ of the total taxa and showed the strongest association in the cluster analysis. Six species were benthic spawners (Tripterygion delaisi, Gobiusculus flavescens, Atherina presbyter, Parablennius pilicornis, Coryphoblennius galerita, Symphodus roissali). All species of this assemblage occurred exclusively within the first two miles from the reef. The only exception was $P$. pilicornis (the most abundant species near the reef) which was also found in Group 3 (7-9 miles). A more detailed analysis of this near-reef assemblage within the first two miles showed that only five out of 23 species were found outside the near-reef stations and they were all more abundant there. The only two species that spread to the second mile presented a significant decrease in their abundances. This was the case of Serranus spp. $(H(2, N=64)=24.33, P<0.001)$ with a significant decrease from the near-reef to the first mile $(P<0.001)$ and to the second mile $(P<0.01)$, and of 
Table 3

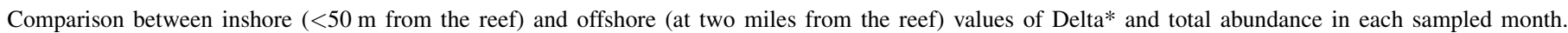
$T=$ value of the $t$-test for independent samples; $Z=$ value of the Mann-Whitney $U$ test; ns $=$ non-significant, $*=P<0.05, * *=P<0.01, * * *=P<0.001$

\begin{tabular}{|c|c|c|c|c|c|c|}
\hline \multirow[t]{2}{*}{ Month } & \multicolumn{3}{|l|}{ Delta* } & \multicolumn{3}{|l|}{ Abundance } \\
\hline & $N$ (Inshore) & $N$ (Offshore) & Statistics & $N$ (Inshore) & $N$ (Offshore) & Statistics \\
\hline May & 15 & 14 & $Z=-2.27 *$ & 15 & 15 & $Z=4.58 * * *$ \\
\hline June & 15 & 14 & $Z=-1.90 \mathrm{~ns}$ & 15 & 15 & $T=4.93 * * *$ \\
\hline July & 15 & 4 & $Z=-2.45 * *$ & 15 & 15 & $Z=-4.67 * * *$ \\
\hline August & 15 & 8 & $T=-0.65 \mathrm{~ns}$ & 15 & 14 & $T=2.15^{*}$ \\
\hline September & - & - & - & 29 & 30 & $Z=1.59 \mathrm{~ns}$ \\
\hline October & 11 & 10 & $T=-0.76 \mathrm{~ns}$ & 15 & 11 & $T=-1.32 \mathrm{~ns}$ \\
\hline
\end{tabular}

$P$. pilicornis that also decreased significantly from the near-reef to the second mile $(P<0.05)$.

\subsubsection{Developmental stage}

As in the inshore/offshore comparison, only larvae in the pre-flexion stage were found for most species (Table 6), and only in six species were more advanced post-flexion larvae collected.

\section{Discussion}

Several factors have been identified as possible causes of changes in the composition of larval assemblages including: temperature (Walker et al., 1987; Houde and Zastrow, 1993); upwelling and wind forcing (Pitts, 1999; Hernandéz-Miranda et al., 2003); current patterns (Cowen and Castro, 1994; Harris et al., 1999; reviewed by Pineda, 2000; Cowen, 2002; Sponaugle et al., 2002). Some studies have, however, shown that temporal changes in composition and abundance may be mostly related to the spawning patterns of adult fishes rather than other biological or physical factors (Sampey et al., 2004).

In our study, most larvae belonged to coastal species associated with shallow water rocky reefs. An annual pattern of variation of this near-reef assemblage was clearly detected, with diversity and total larval abundance higher from May to July. This corresponds with the breeding season for most coastal species occurring at the Arrábida Marine Park (Henriques et al., 1999; Gonçalves et al., 2003). In August, larval abundance and diversity decreased abruptly, which is in accordance with the end of the spawning activity for most species. Other studies of temperate nearshore waters have also found that spring and summer are periods of high larval abundances and highest diversity values (Palomera and Olivar, 1996; Sabatés et al., 2003). However, in some cases, in spite of the higher abundance of larvae found closer to shore, distribution patterns of larval assemblages were weakly related to the spawning mode of adults (Kingsford and Choat, 1989; Gray, 1993; Brogan, 1994; Hickford and Schiel, 2003).

Clear temporal patterns of variation in diversity, abundance and structure of the inshore assemblages were found, but these were not so evident offshore. Nevertheless, diversity and total larval abundance decreased with increasing distance from the reef, both in the inshore/offshore comparison and in transects. This decrease was evident at a small spatial scale, immediately after the first mile from the reef. Moreover, all taxa present in transects also occurred, and were in general more abundant in inshore waters, indicating a probable reef origin. Four different assemblages could be identified, with the strongest association corresponding to species which were collected almost exclusively near the reef. This result suggests a common local origin but different patterns of dispersal for different species and/or in different periods of the year. The absence of larvae from oceanic species could be explained by an off-reef displacement of surface waters caused by upwelling events, which take place very close to our study area during summer months (Fiúza, 1982), or to more offshore location of the spawning areas for these species.

While Leis and Miller (1976) described contrasting patterns of distribution for species hatching from pelagic and benthic eggs with distance to reefs, our results do not follow this trend. There was no clear distinction on the distribution of larvae from demersal and pelagic spawners with distance to the reef.

Larvae hatching from pelagic eggs that were present in inshore assemblages included carangids, engraulids, soleids and serranids and high numbers of the clupeid Sardina pilchardus. On the other hand, near-reef larvae from demersal spawners included Tripterygion delaisi, Gobiusculus flavescens, Atherina presbyter, Lepadogaster lepadogaster, Parablennius gattorugine, Coryphoblennius galerita, Pomatoschistus pictus, Gobius and Symphodus. From these, the first four species were restricted to the near-reef, while C. galerita and Symphodus roissali were found also within the first mile from the reef. These results contrast with those of other studies that recorded larvae of G. flavescens, C. galerita, P. pictus, L. lepadogaster and Atherina offshore (see Russell, 1973; Fives and O’Brien, 1976; Riley et al., 1986; Acevedo et al., 2002; Lee et al., 2005).

Among the species that showed a more "dispersive" pattern of distribution with larvae being found at greater distances from the reef, no clear pattern was also found between pelagic and demersal spawners. Larvae from pelagic spawners included Sardina pilchardus, Mullus surmuletus and several sparids. Among the pelagic spawners, S. pilchardus is the most abundant species spawning off the Portuguese coast (Ré et al., 1990) and high densities of larvae have been found by other authors over shelf waters (Lopes and Afonso, 1995). Mullets are coastal species frequently found in estuaries but spawning at sea (Ben-Tuvia, 1986; own observations), and larvae of these species were abundant in our samples. Mullus surmuletus 
Table 4

Similarity percentages analysis (SIMPER) results for each month at the inshore and offshore samples. Average similarity values, average abundance and percentage contribution of the most representative species to the average similarity within each group are shown. Cut off for low contributions $=95 \%$. Av.Abund $=$ average abundance. Sim $/ \mathrm{SD}=$ similarity/standard deviation. Contrib $\%=$ percentage of each species contribution to the average similarity between samples. Cum $\%=$ cumulative percentage

\begin{tabular}{|c|c|c|c|c|c|c|c|c|c|}
\hline SIMPER & \multicolumn{5}{|l|}{ Inshore } & \multicolumn{4}{|l|}{ Offshore } \\
\hline \multirow{2}{*}{$\begin{array}{l}\text { May } \\
\text { Species group } 1\end{array}$} & \multicolumn{5}{|c|}{ Average similarity: 32.93} & \multicolumn{4}{|c|}{ Average similarity: 13.97} \\
\hline & Av.Abund & $\mathrm{Sim} / \mathrm{SD}$ & Contrib\% & Cum.\% & Species group 7 & Av.Abund & $\mathrm{Sim} / \mathrm{SD}$ & Contrib\% & Cum.\% \\
\hline Parablennius pilicornis & 120.02 & 1.05 & 41.49 & 41.49 & Parablennius pilicornis & 20.6 & 0.39 & 34 & 34 \\
\hline Sardina pilchardus & 114.86 & 1.08 & 27.9 & 69.39 & Diplodus spp. & 13.69 & 0.26 & 19.43 & 53.43 \\
\hline Sparidae sp1 & 65.57 & 0.6 & 12.28 & 81.67 & Gobius niger type & 13.02 & 0.26 & 12.12 & 65.56 \\
\hline Diplodus spp. & 41.73 & 0.52 & 7.22 & 88.89 & Mullus surmuletus & 7.37 & 0.17 & 10.9 & 76.46 \\
\hline Sparidae n.i. & 13.67 & 0.31 & 1.69 & 90.58 & Belone spp. & 14.05 & 0.26 & 10.4 & 86.86 \\
\hline Tripterygion delaisi & 26.61 & 0.21 & 1.61 & 92.19 & Sparidae sp3 & 13.89 & 0.26 & 10.05 & 96.91 \\
\hline Parablennius gattorugine & 18.86 & 0.22 & 1.19 & 93.38 & & & & & \\
\hline Symphodus melops type & 11.49 & 0.24 & 1.13 & 94.5 & & & & & \\
\hline Arnoglossus spp. & 12.69 & 0.23 & 0.96 & 95.47 & & & & & \\
\hline
\end{tabular}

\begin{tabular}{|c|c|c|c|c|c|c|c|c|c|}
\hline \multirow[b]{2}{*}{ Species group 2} & \multicolumn{5}{|c|}{ Average similarity: 23.26} & \multicolumn{4}{|c|}{ Average similarity: 24.82} \\
\hline & Av.Abund & $\mathrm{Sim} / \mathrm{SD}$ & Contrib\% & Cum.\% & Species group 8 & Av.Abund & $\mathrm{Sim} / \mathrm{SD}$ & Contrib\% & Cum. $\%$ \\
\hline Sparidae sp1 & 59.16 & 1 & 48.59 & 48.59 & Sparidae sp1 & 32.72 & 0.6 & 49.91 & 49.91 \\
\hline Gobius niger type & 56.38 & 0.42 & 11.9 & 60.5 & Gobius niger type & 26.49 & 0.62 & 45.57 & 95.48 \\
\hline Coryphoblennius galerita & 20.98 & 0.46 & 10.16 & 70.66 & & & & & \\
\hline Symphodus roissali & 22.01 & 0.35 & 7.55 & 78.21 & & & & & \\
\hline Tripterygion delaisi & 24.37 & 0.39 & 6.02 & 84.23 & & & & & \\
\hline Parablennius pilicornis & 27.02 & 0.29 & 5.61 & 89.84 & & & & & \\
\hline Sardina pilchardus & 14.73 & 0.3 & 4.45 & 94.29 & & & & & \\
\hline Coris julis & 11.1 & 0.24 & 1.92 & 96.21 & & & & & \\
\hline
\end{tabular}

\begin{tabular}{|c|c|c|c|c|c|c|c|c|c|}
\hline \multirow[b]{2}{*}{ Species group 3} & \multicolumn{5}{|c|}{ Average similarity: 37.75} & \multicolumn{4}{|c|}{ Average similarity: 9.82} \\
\hline & Av.Abund & $\mathrm{Sim} / \mathrm{SD}$ & Contrib\% & Cum.\% & Species group 9 & Av.Abund & $\mathrm{Sim} / \mathrm{SD}$ & Contrib\% & Cum.\% \\
\hline Parablennius pilicornis & 270.92 & 1.4 & 50.22 & 50.22 & Serranus cabrilla & 25.19 & 0.41 & 100 & 100 \\
\hline Serranus spp. & 142.13 & 1.28 & 27.6 & 77.82 & & & & & \\
\hline Sparidae sp1 & 59.17 & 0.7 & 8.92 & 86.74 & & & & & \\
\hline Coris julis & 37.55 & 0.45 & 3.43 & 90.16 & & & & & \\
\hline Coryphoblennius galerita & 32.56 & 0.35 & 2.62 & 92.79 & & & & & \\
\hline Pagellus sp1 & 15.22 & 0.28 & 1.61 & 94.39 & & & & & \\
\hline Symphodus roissali & 17.1 & 0.29 & 1.34 & 95.74 & & & & & \\
\hline
\end{tabular}

\begin{tabular}{|c|c|c|c|c|c|c|c|c|c|}
\hline \multirow[b]{2}{*}{ Species group 4} & \multicolumn{5}{|c|}{ Average similarity: 16.66} & \multicolumn{4}{|c|}{ Average similarity: 16.94} \\
\hline & Av.Abund & $\mathrm{Sim} / \mathrm{SD}$ & Contrib\% & Cum. $\%$ & Species group 10 & Av.Abund & $\mathrm{Sim} / \mathrm{SD}$ & Contrib\% & Cum.\% \\
\hline Coryphoblennius galerita & 15.81 & 0.39 & 27.3 & 27.3 & Parablennius pilicornis & 39.73 & 0.96 & 69.82 & 69.82 \\
\hline Serranus spp. & 21.72 & 0.46 & 26.67 & 53.97 & Serranus spp. & 12.09 & 0.33 & 12.74 & 82.56 \\
\hline Sardina pilchardus & 30.03 & 0.39 & 20.57 & 74.54 & Mugilidae n.i. & 7.76 & 0.19 & 6.87 & 89.43 \\
\hline Trachurus trachurus & 9.73 & 0.22 & 5.99 & 80.53 & Sparidae sp3 & 7.41 & 0.19 & 5.99 & 95.41 \\
\hline Sparidae sp1 & 8.72 & 0.23 & 5.88 & 86.4 & & & & & \\
\hline Ctenolabrus rupestris & 7.18 & 0.17 & 5.57 & 91.97 & & & & & \\
\hline Trachinus draco & 11.45 & 0.17 & 3.4 & 95.37 & & & & & \\
\hline
\end{tabular}

\begin{tabular}{|c|c|c|c|c|c|c|c|c|c|c|}
\hline \multirow[t]{2}{*}{ Sep } & \multicolumn{10}{|c|}{ Average similarity: 16.37} \\
\hline & Species group 5 & Av.Abund & $\mathrm{Sim} / \mathrm{SD}$ & Contrib\% & Cum.\% & & & & & \\
\hline & Parablennius pilicornis & 19.33 & 0.58 & 100 & 100 & & & & & \\
\hline \multirow[t]{6}{*}{ Oct } & \multicolumn{6}{|c|}{ Average similarity: 16.22} & \multicolumn{4}{|c|}{ Average similarity: 12.72} \\
\hline & Species group 6 & Av.Abund & $\mathrm{Sim} / \mathrm{SD}$ & Contrib\% & Cum.\% & Species group 11 & Av.Abund & $\mathrm{Sim} / \mathrm{SD}$ & Contrib\% & Cum.\% \\
\hline & Sardina pilchardus & 37.49 & 0.53 & 63.1 & 63.1 & Mugilidae n.i. & 33.46 & 0.52 & 57.66 & 57.66 \\
\hline & Lisa ramada & 11.63 & 0.23 & 15.21 & 78.32 & Sardina pilchardus & 11.49 & 0.25 & 31.93 & 89.59 \\
\hline & Pagellus sp1 & 13.73 & 0.34 & 15.15 & 93.47 & Ammodytidae n.i. & 10.55 & 0.15 & 6.52 & 96.11 \\
\hline & Mugilidae n.i. & 11.42 & 0.13 & 6.53 & 100 & & & & & \\
\hline
\end{tabular}


Table 5

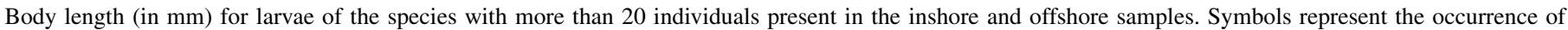
larvae in each developmental stage: $\boldsymbol{\Delta}$ pre-flexion;

\begin{tabular}{|c|c|c|c|c|c|c|c|c|c|c|}
\hline \multirow[t]{2}{*}{ Species } & \multicolumn{5}{|l|}{ Inshore } & \multicolumn{5}{|l|}{ Offshore } \\
\hline & Developmental stage & $N$ & Mean & SD & Range & Developmental stage & $N$ & Mean & $\mathrm{SD}$ & Range \\
\hline Coris julis & $\mathbf{\Delta}$ & 21 & 2.30 & 0.50 & $1.58-3.35$ & $\boldsymbol{\Delta}$ & 4 & 2.44 & 0.91 & $1.72-3.70$ \\
\hline Coryphoblennius galerita & $\mathbf{\Delta}$ & 37 & 3.48 & 1.10 & $2.80-9.80$ & - & 0 & - & - & - \\
\hline Diplodus spp. & $\Delta$ & 23 & 3.88 & 1.22 & $2.65-6.90$ & $\Delta$ & 6 & 3.90 & 0.47 & $3.25-4.50$ \\
\hline Gobius niger type & $\boldsymbol{\Delta}$ & 30 & 3.08 & 0.81 & $1.95-5.05$ & $\Delta$ & 19 & 3.00 & 0.50 & $2.25-3.90$ \\
\hline Parablennius pilicornis & $\Delta$ & 175 & 2.77 & 0.57 & $1.85-9.80$ & $\Delta \mathbf{O}$ & 20 & 2.96 & 0.60 & $2.15-4.45$ \\
\hline Sardina pilchardus & $\Delta$ & 86 & 5.53 & 1.51 & $3.00-14.50$ & $\Delta$ & 3 & 4.62 & 1.27 & $3.50-6.00$ \\
\hline Serranus spp. & $\mathbf{\Delta}$ & 61 & 2.19 & 0.29 & $1.52-2.85$ & $\Delta$ & 4 & 2.01 & 0.36 & $1.50-2.35$ \\
\hline Sparidae sp1 & $\boldsymbol{\Delta}$ & 83 & 2.21 & 0.78 & $1.25-4.60$ & $\Delta$ & 17 & 2.20 & 0.90 & $1.32-4.00$ \\
\hline n.i. & $\Delta$ & 83 & 1.73 & 0.41 & $1.10-2.75$ & $\Delta$ & 33 & 1.78 & 0.51 & $1.10-2.95$ \\
\hline
\end{tabular}

is a benthic species inhabiting shallow waters, but with a clear dispersive pattern. For this species, our observations agree with those of Russell (1973) off Plymouth (England) and Deudero (2002) in the Mediterranean, with more larvae found in the group of miles further distant from the reef in transects. Coris julis is a reef associated species that also hatches from pelagic eggs and has been described to disperse in shelf waters (Sabatés et al., 2003).

Offshore larvae included larvae from demersal spawners like Gobius niger type. This is a nearshore species often found in estuaries and lagoons (Miller, 1986). However, larvae of this species can be abundant in more offshore waters (Fives and O'Brien, 1976; Tully and O'Ceidigh, 1989; Acevedo et al., 2002; Koutrakis et al., 2004). Parablennius gattorugine and Symphodus melops type larvae were also present offshore which agrees with the results of Russell (1973), Fives and O'Brien (1976), Tully and O'Ceidigh (1989), Riley et al (1986), Koutrakis et al. (2004) and Lee et al. (2005), and of Afonso (1995) for the Portuguese coast. Parablennius pilicornis and Belone spp. were other demersal spawners found away from the reef.

Larval retention near-reefs depends on complex interactions between biological and physical factors, with some

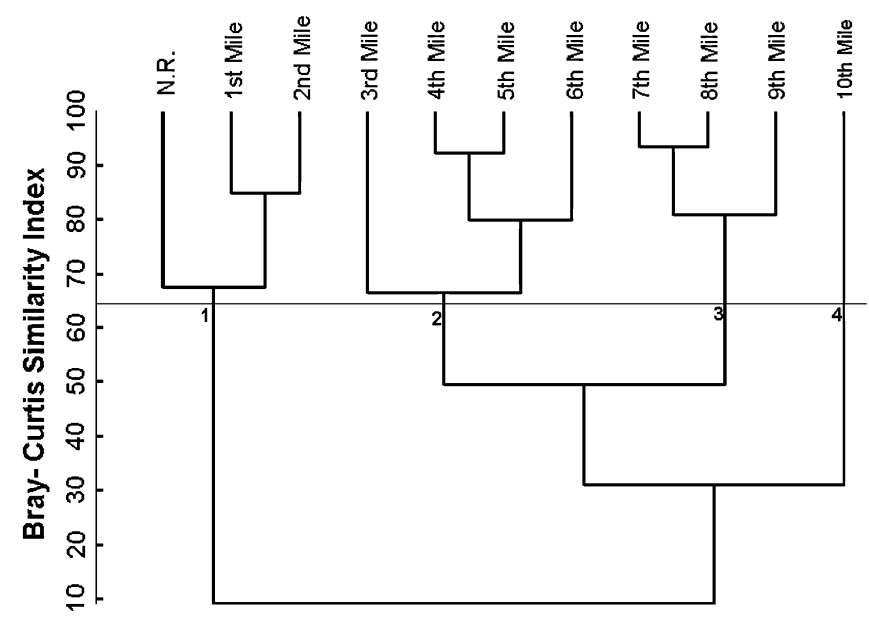

Fig. 5. Groups of miles $(1-4)$ as defined by the Q-mode clustering with contiguity constraint. N.R. = Near-reef. nearshore environments having particular oceanographic features that can facilitate larval retention (Harris et al., 1999; Pineda, 2000; Sanvicente-Añorve et al., 2000; Sponaugle et al., 2002; Largier, 2003). At our study area, the mix of factors possibly affecting dispersal must be further investigated. Although nothing is known on the micro-scale circulation patterns in this area, there are, however, a number of features which could potentially act as retention mechanisms. A possible interaction between shallow depths, bottom complexity and the prevailing alongshore (west-east direction) currents exists, which may create layers of flows with different directions (Largier, 2003). In these conditions, it is known that water flow is often slowed near the epibenthic boundary layer, increasing the potential retention of larvae that stay near the bottom (Breitburg et al., 1995). Moreover, sampling in the leeward and windward locations in islands has shown differences in larval distribution patterns (Leis, 1991). A high degree of self-recruitment has also been found in sheltered assemblages in the lee side of islands (Jones et al., 1999; Swearer et al., 1999; Jones et al., 2005). Wind forcing is therefore another factor that can have a strong influence over dispersal (Cowen, 2002). At the Arrábida Marine Park this force is greatly reduced due to the geomorphology of the coastline. In addition, in the nearby coastal area, upwelling events occur frequently in the spring/summer months (Fiúza, 1982) with known relaxation episodes related to the shadow effect of the coastline (Moita et al., 2003). This phenomenon has been described as an important retention mechanism for planktonic organisms in other coastal systems (Cowen, 2002; Hernandéz-Miranda et al., 2003; Roughan et al., 2005a,b). Finally, the interaction between slope topography and tidal flow creates vertical eddies at the mouth of the nearby Sado River (Martins et al., 2001, 2002). The extent to which these eddies influence the hydrodynamics of the nearshore area is not known. The highest larval densities and diversity found near-reefs could result from a gradient relative to the estuary mouth rather than to the reefs themselves. However, our fine scale results showed no apparent gradients in relation to the estuary location. Furthermore, larval density was found to be homogeneous alongshore at the near-reef locations of the Arrábida Marine Park (own unpublished results). Nonetheless, it would be interesting in the future to 

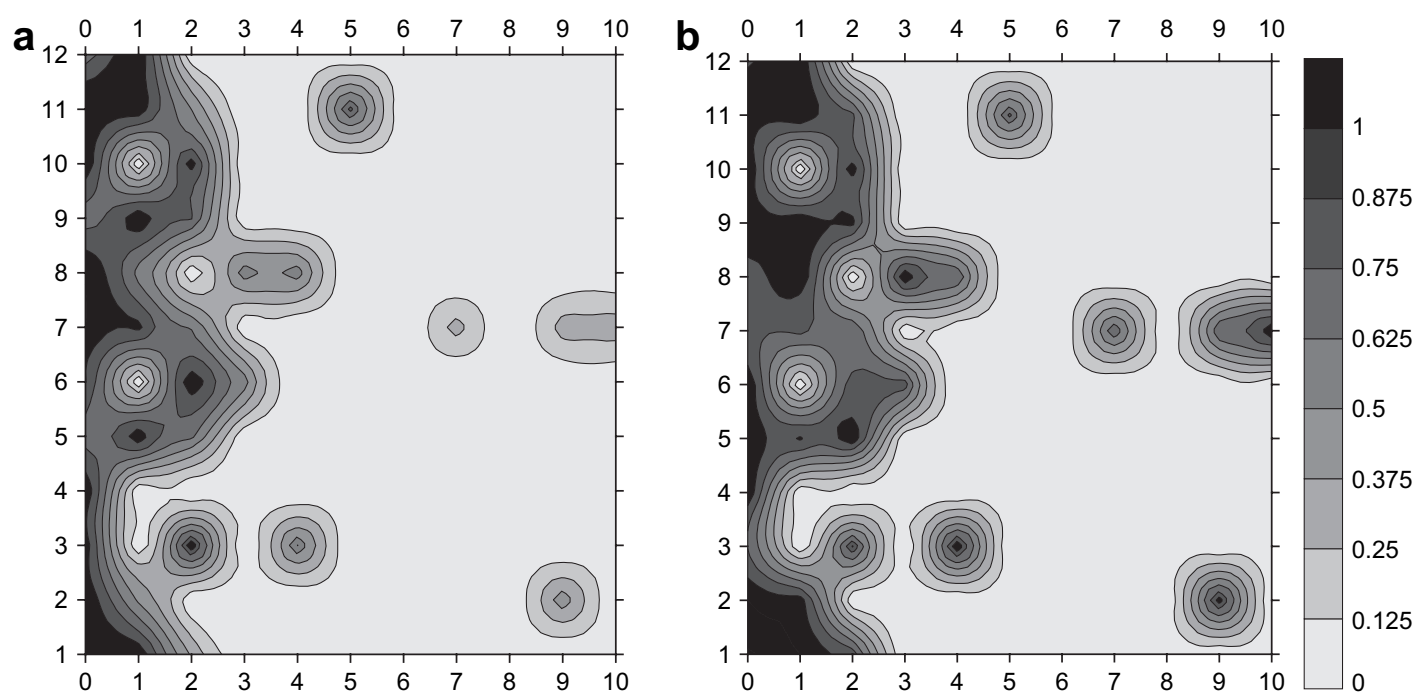

Fig. 6. Spatial distribution of normalized values of diversity indices along the 12 transects. Stations are shown from left to right (respectively from the near-reef to the 10th mile). (a) Shannon diversity index $\left(H^{\prime}\right)$; (b) average taxonomic index (Delta*).

investigate which species may be using the estuary as nursery areas before migrating to the reefs.

Internal tides also occur in the adjacent coastal area (J. Silva, personal communication) and have the potential to promote the shoreward transport of organisms. This can also be an important mechanism associated with recruitment peaks for some coastal species with planktonic larvae (Pineda, 1994, 2000; Lamb, 1997). The high abundance of larvae from pelagic eggs found inshore can be indicative that such passive retention of planktonic organisms may be occurring at the Arrábida Marine Park. The described physical mechanisms could retain eggs and recently hatched larvae near the reefduring the first days of development, while sensory abilities develop. Some larvae could then actively behave in response to those environmental features, regulating their position in the water column, thus avoiding dispersal. The onset of these behavioural capabilities could influence the dispersal patterns differently, depending on the species. This could explain the different patterns found between species with similar life histories and spawning modes: larvae of some species whose adults live associated with the benthic rocky environment and spawning demersal eggs seem to be retained near the reef, while for other species larval dispersal seems to be more evident. The larval strong swimming abilities of some coral reef (reviewed by Cowen, 2002; Leis and McCormick, 2002; Sponaugle et al., 2002; Fisher, 2005) and temperate rocky reef species (Dudley et al., 2000; Leis et al., 2006), provides evidence that dispersal patterns of reef fish species can be strongly influenced by specific larval behaviours.

Nearshore retention could also be facilitated for some species hatching from benthic eggs and having short planktonic larval durations. For instance, Tripterygion delaisi larvae were only found at the near-reef samples. Although Hickford and Schiel (2003) found Tripterygiidae larvae of all size classes away from shore, this is the taxon that most consistently has been referred to be retained near-reefs (Marliave, 1986;
Kingsford and Choat, 1989; Tilney et al., 1996; Sabatés et al., 2003). Another taxon often associated with nearshore environments is the family Gobiidae (Leis, 1991). Nevertheless, Gobius niger type larvae were found occurring offshore, and this and other Gobiidae larvae are present near the inshore rocky bottom within all size classes (unpublished results). In addition, there is also some evidence of retention for species from the family Gobiesocidae which lay large benthic eggs and have short planktonic larval durations (Marliave, 1986; Tilney et al., 1996; Sabatés et al., 2003). Although Lepadogaster lepadogaster have also been found offshore (e.g. Lee et al., 2005), we have caught large numbers of gobiesocid larvae of all size classes with light traps near the reefs (R. Borges and E.J. Gonçalves, unpublished data).

\section{Conclusions}

From our results it is premature to make definitive conclusions on the mechanisms explaining the patterns of nearshore larval distribution at the Arrábida Marine Park. In fact, the reduced larval densities found with increasing distance from the reef are not necessarily linked to nearshore larval retention. The sampling method used only sampled the surface water layer and therefore did not include the vertical profile of larval distribution. It is well known that these vertical profiles exist for a number of species occurring in shelf waters (reviewed by Neilson and Perry, 1990). Moreover, the fact that most larvae were in the pre-flexion stage suggests a high degree of local production at our study area. The Arrábida Marine Park may therefore be a spawning ground for coastal fish species. Our results also show that, at least in surface waters, late stage larvae were absent or rare. Therefore, to better understand the specific dispersal patterns and retention mechanisms at this site, it is crucial to have information on the distribution patterns of all size class larvae. One possible explanation for the scarcity of bigger larvae in our samples 

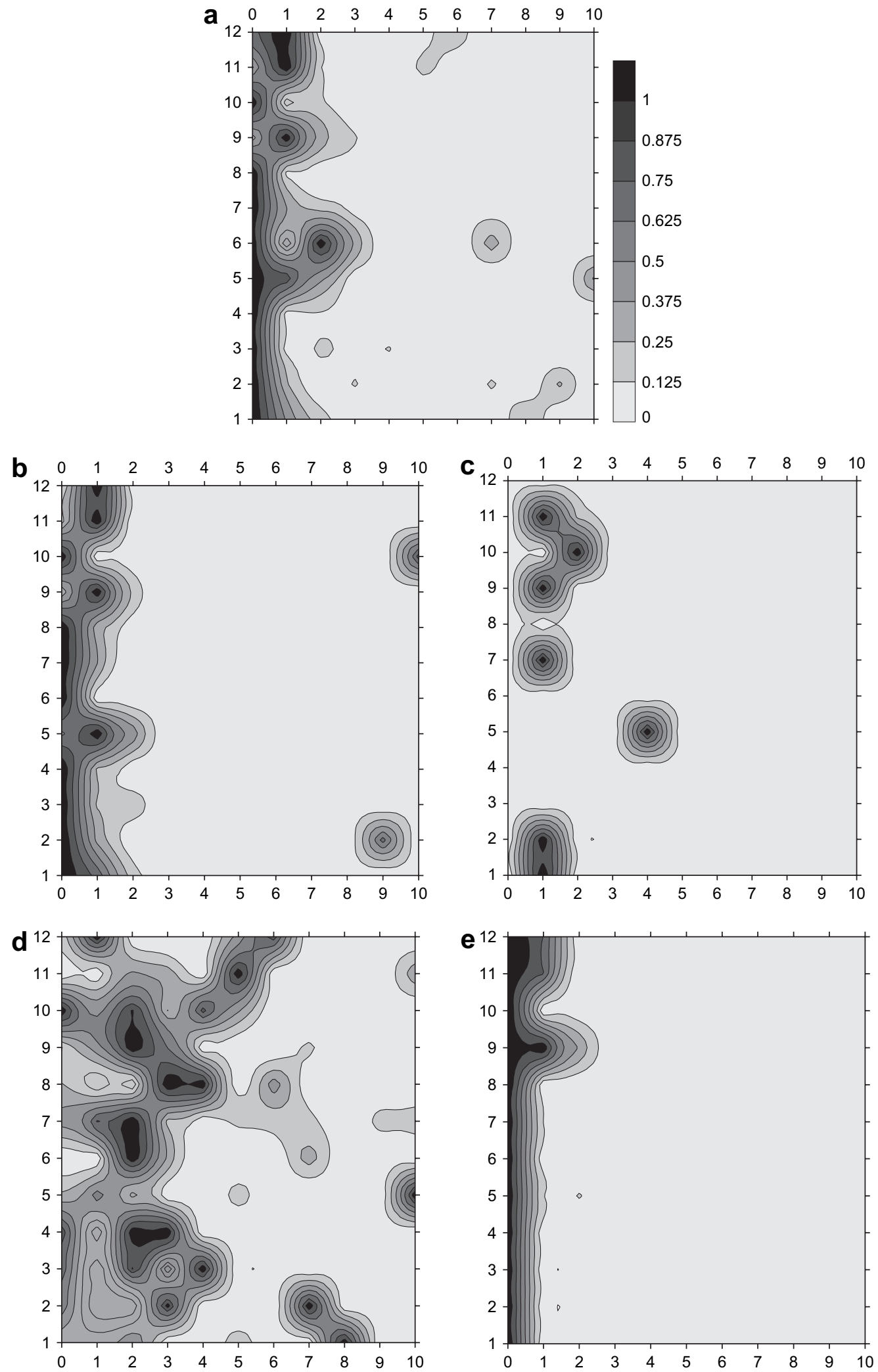

Fig. 7. Spatial distribution of normalized values of larval abundance along the 12 transects. Stations are shown from left to right (respectively from the near-reef to the 10th mile). (a) Total abundance; (b) Larval abundance in the first species assemblage; (c) Larval abundance in the second species assemblage; (d) Larval abundance in the third species assemblage; (e) Larval abundance in the fourth species assemblage. 
Table 6

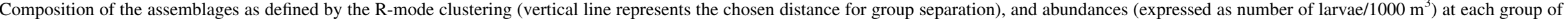
miles defined by the Q-mode clustering. Body length range (in $\mathrm{mm}$ ) is expressed for each species. Symbols represent the occurrence of larvae in each developmental stage: $\boldsymbol{\Delta}$ pre-flexion; $\boldsymbol{O}$ incomplete flexion;

post-flexion

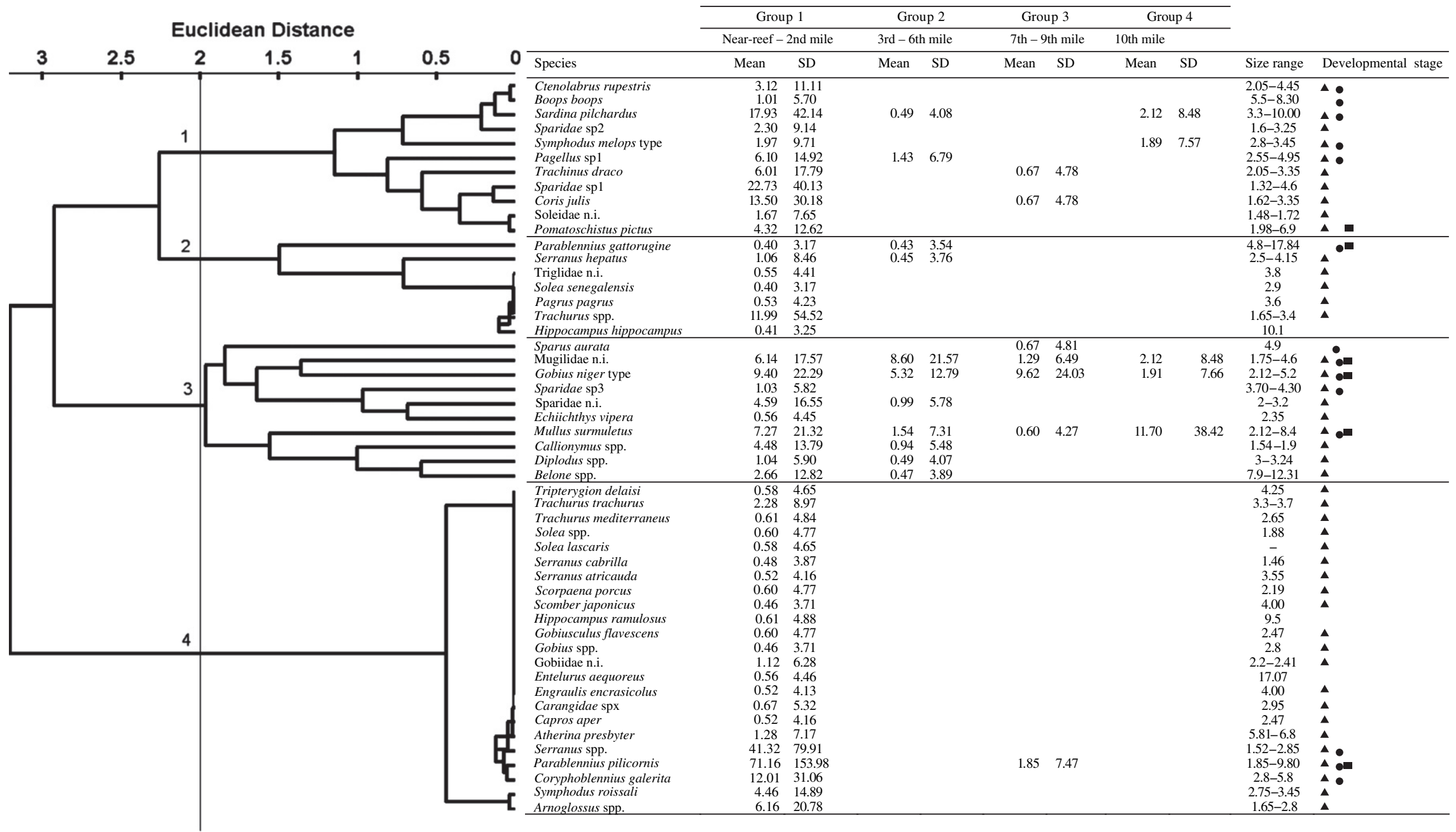


could be net avoidance by the larvae. However it seems unlikely that all taxa found would present the same degree of avoidance and some more advanced larvae were found for some species.

Furthermore, bigger larvae were caught with a similar net dragged near the rocky reef attached to an underwater scooter, indicating that more developed larvae occur near the substrate (R. Beldade, R. Borges and E.J. Gonçalves, unpublished data). Offshore dispersal is another possibility for some species. Knowing the extent to which the physical processes operating in the area affect larval dispersal, the vertical profile of distribution for these assemblages, and the detailed ontogeny of behaviours and sensory skills of larvae, will further help understand the factors influencing the dispersal patterns for the different species in these nearshore assemblages. Understanding the degree of dispersal of those larvae produced at the Arrábida Marine Park can be, in turn, also useful to fisheries management given that higher retention of some species means that larval export to fished populations can be lower than expected, while for other species no-take areas implemented at their spawning locations may enhance fisheries elsewhere.

\section{Acknowledgements}

This study was supported by the Portuguese Science and Technology Foundation (Fundação para a Ciência e a Tecnologia - FCT) as part of the project POCTI/BSE/38350/2001 and through the Pluriannual Program (R\&D Unit 331/94). FCT also supported the Ph.D. grant of R. Borges (SFRH/BD/ 4852/2001). We would like to thank M. Barbosa, R. Beldade, V. Carvalho, A. Catarino, J. Martins, N. Sousa and S. Vizinho for assistance in the field and lab work, the Oceanographic Museum of Parque Natural da Arrábida for all the support and two anonymous referees for valuable comments to the manuscript. Sampling and laboratory procedures comply with current Portuguese legislation.

\section{References}

Acevedo, S., Dwane, O., Fives, J.M., 2002. The community structure of larval fish populations in an area of the Celtic Sea in 1998. Journal of the Marine Biological Association of the United Kingdom 82, 641-648.

Afonso, M.H., 1995. Ictioplâncton na zona sudoeste da Costa Continental Portuguesa. Boletim Instituto Português de Investigação Marítima, Lisboa 1, $5-22$.

Atema, J., Kingsford, M.J., Gerlach, G., 2002. Larval reef fish could use odour for detection, retention and orientation to reefs. Marine Ecology Progress Series 241, 151-160.

Bardi, G., Friedländer, R. (Eds.), 1931-1956. Fauna e Flora del Golfo di Napoli. Uova, larvi e stadî giovanili di Teleostei. Stazioni Zoologica di Napoli, Napoli, Monografia 38, 1057 pp.

Ben-Tuvia, A., 1986. Mugilidae. In: Whitehead, P.J.P. (Ed.), Fishes of the North-eastern Atlantic and the Mediterranean (FNAM). UNESCO, Paris, pp. 1197-1204.

Boehlert, G.W., Mundy, B.C., 1988. Roles of behavioral and physical factors in larval and juvenile fish recruitment to estuarine and nursery areas. American Fisheries Society Symposium 3, 51-67.
Breitburg, D.L., Palmer, M.A., Loher, T., 1995. Larval distributions and the spatial patterns of settlement of an oyster reef fish: responses to flow and structure. Marine Ecology Progress Series 125, 45-60.

Brogan, M.W., 1994. Distribution and retention of larval fishes near reefs in the Gulf of California. Marine Ecology Progress Series 115, 1-13.

Caley, M.J., Carr, M.H., Hixon, M.A., Hughes, T.P., Jones, G.P., Menge, B.A., 1996. Recruitment and the local dynamics of open marine populations. Annual Review in Ecology and Systematics 27, 477-500.

Caselle, J.E., Hamilton, S.L., Warner, R.R., 2003. The interaction of retention, recruitment, and spatial placement of marine reserves. Gulf and Caribbean Research 14, 107-118.

Clarke, K.R., Warwick, R.M., 2001. Change in Marine Communities: An Approach to Statistical Analysis and Interpretation. PRIMER-E Ltd., Plymouth, 144 pp.

Cowen, R.K., 2002. Larval dispersal and retention and consequences for population connectivity. In: Sale, P.F. (Ed.), Coral Reef Fishes: Dynamics and Diversity in a Complex Ecosystem. Academic Press, San Diego, pp. 149-170.

Cowen, R.K., Castro, L.R., 1994. Relation of coral reef fish larval distributions to island scale circulation around Barbados, West Indies. Bulletin of Marine Science 54, 228-244.

Cowen, R.K., Sponaugle, S., 1997. Relationships between early life history traits and recruitment among coral reef fishes. In: Chambers, R.C., Trippel, E.A. (Eds.), Early Life History and Recruitment in Fish Populations. Chapman \& Hall, London, pp. 423-449.

Deudero, S., 2002. Unexpected large numbers of Mullus surmuletus juveniles in open waters of the Mediterranean sampled with light attraction devices. Journal of Fish Biology 61, 1639-1642.

Doherty, P.J., 1991. Spatial and temporal patterns in recruitment. In: Sale, P.F. (Ed.), The Ecology of Fishes on Coral Reefs. Academic Press, San Diego, pp. 261-293.

Dudley, B., Tolimieri, N., Montgomery, J., 2000. Swimming ability of the larvae of some reef fishes from New Zealand waters. Marine and Freshwater Research 51, 783-787.

Fisher, R., 2005. Swimming speeds of larval coral reef fishes: impacts on selfrecruitment and dispersal. Marine Ecology Progress Series 285, 223-232.

Fisher, R., Bellwood, D.R., 2002. The influence of swimming speed on sustained swimming performance of late-stage reef fish larvae. Marine Biology 140, 801-807.

Fisher, R., Bellwood, D.R., 2003. Undisturbed swimming behaviour and nocturnal activity of coral reef fish larvae. Marine Ecology Progress Series 263, 177-188.

Fiúza, A.F.G., 1982. The Portuguese coastal upwelling system. In: Actual Problems of Oceanography in Portugal. Junta Nacional de Investigação Científica e Tecnológica, Lisbon, pp. 45-71.

Fives, J.M., O’Brien, F.I., 1976. Larval and post-larval stages of fishes recorded from the plankton of Galway Bay, 1972-73. Journal of the Marine Biological Association of the United Kingdom 56, 197-211.

Gonçalves, E.J., Henriques, M., Almada, V.C., 2003. Use of a temperate reeffish community to identify priorities in the establishment of a Marine Protected Area. Aquatic Protected Areas. In: Beumer, J.P., Grant, A., Smith, D.C. (Eds.), Aquatic Protected Areas: What Works Best and How Do We Know? Proceedings of the World Congress on Aquatic Protected Areas, Cairns, August 2002. Australian Society for Fish Biology, North Beach, WA, pp. 261-272.

Gray, C.A., 1993. Horizontal and vertical trends in the distributions of larval fishes in coastal waters off central New South Wales, Australia. Marine Biology 116, 649-666.

Harris, S.A., Cyrus, D.P., Beckley, L.E., 1999. The larval fish assemblage in nearshore coastal waters off the St. Lucia estuary, South Africa. Estuarine, Coastal and Shelf Science 49, 789-811.

Henriques, M., Gonçalves, E.J., Almada, V.C., 1999. The conservation of littoral fish communities: a case study at Arrábida coast (Portugal). In: Almada, V.C., Oliveira, R.F., Gonçalves, E.J. (Eds.), Behaviour and Conservation of Littoral Fishes. Instituto Superior de Psicologia Aplicada, Lisboa, pp. 473-519.

Hernandéz-Miranda, E., Palma, A.T., Ojeda, F.P., 2003. Larval fish assemblages in nearshore coastal waters off central Chile: temporal and spatial patterns. Estuarine, Coastal and Shelf Science 56, 1075-1092. 
Hickford, M.J.H., Schiel, D.R., 2003. Comparative dispersal of larvae from demersal versus pelagic spawning fishes. Marine Ecology Progress Series 252, 255-271.

Houde, E.D., Zastrow, C.E., 1993. Ecosystem- and taxon-specific dynamic and energetics properties of larval fish assemblages. Bulletin of Marine Science 53, 290-335.

Irisson, J.-O., LeVan, A., De Lara, M., Planes, S., 2004. Strategies and trajectories of coral reef fish larvae optimizing self-recruitment. Journal of Theoretical Biology 227, 205-218.

Jenkins, G.P., Keough, M.J., Hamer, P.A., 1998. The contributions of habitat structure and larval supply to broad-scale recruitment variability in a temperate zone, seagrass-associated fish. Journal of Experimental Biology and Ecology 226, 259-278.

John, H.-C., Ré, P., 1993. Cross-shelf zonation, vertical distribution, and drift of fish larvae off northern Portugal during weak upwelling. International Council for the Exploration of the Sea, 1-18 (C.M.1993/L:33).

Jones, G.P., Milicich, M.J., Emslie, M.J., Lunow, C., 1999. Self-recruitment in a coral reef fish population. Nature 402, 802-804.

Jones, G.P., Planes, S., Thorrold, S.R., 2005. Coral reef fish larvae settle close to home. Current Biology 15, 1314-1318.

Kingsford, M.J., Choat, J.H., 1989. Horizontal distribution patterns of presettlement reef fish: are they influenced by the proximity of reefs? Marine Biology 101, 285-297.

Kingsford, M.J., Leis, J.M., Shanks, A., Lindeman, K.C., Morgan, S.G., Pineda, J., 2002. Sensory environments, larval abilities and local selfrecruitment. Bulletin of Marine Science 70, 309-340.

Koutrakis, E.T., Kallianiotis, A.A., Tsikliras, A.C., 2004. Temporal patterns of larval fish distribution and abundance in a coastal area of northern Greece. Scientia Marina 68, 585-595.

Lamb, K.G., 1997. Particle transport by nonbreaking, solitary internal waves. Journal of Geophysical Research 102, 18,641-18,660.

Largier, J.L., 2003. Considerations in estimating larval dispersal distances from oceanographic data. Ecological Applications 13, S71-S89.

Lee, O., Nash, R.D.M., Danilowicz, B.S., 2005. Small-scale spatio-temporal variability in ichthyoplankton and zooplankton distribution in relation to a tidal-mixing front in the Irish Sea. ICES Journal of Marine Science 62, 1021-1036.

Legendre, P., Legendre, L., 1998. Numerical Ecology. Developments in Environmental Modelling. Elsevier, 853 pp.

Leis, J.M., 1991. The pelagic stage of reef fishes: the larval biology of coral reef fishes. In: Sale, P.F. (Ed.), The Ecology of Fishes on Coral Reefs. Academic Press, San Diego, pp. 183-230.

Leis, J.M., 2002. Pacific coral-reef fishes: the implications of behaviour and ecology of larvae for biodiversity and conservation, and a reassessment of the open population paradigm. Environmental Biology of Fishes 65, 199-208.

Leis, J.M., 2003. What does larval fish biology tell us about the design and efficacy of Marine Protected Areas? In: Beumer, J.P., Grant, A., Smith, D.C. (Eds.), Aquatic Protected Areas: What Works Best and How Do We Know? Proceedings of the World Congress on Aquatic Protected Areas, Cairns, August 2002. Australian Society for Fish Biology, North Beach, WA, pp. 170-180.

Leis, J.M., Carson-Ewart, B.M., 2000. The Larvae of Indo-Pacific Coastal Fishes. An Identification Guide to Marine Fish Larvae. Brill, Leiden, $850 \mathrm{pp}$.

Leis, J.M., Carson-Ewart, B.M., Cato, D.H., 2002. Sound detection in situ by the larvae of a coral-reef damselfish (Pomacentridae). Marine Ecology Progress Series 232, 259-268.

Leis, J.M., Carson-Ewart, B.M., Hay, A.C., Cato, D.H., 2003. Coral-reef sounds enable nocturnal navigation by some reef-fish larvae in some places and at some times. Journal of Fish Biology 63, 724-737.

Leis, J.M., Hay, A.C., Trnski, T., 2006. In situ ontogeny of behaviour in pelagic larvae of three temperate, marine, demersal fishes. Marine Biology $148,655-669$.

Leis, J.M., Lockett, M., 2005. Localization of reef sounds by settlement-stage larvae of coral-reef fishes (Pomacentridae). Bulletin of Marine Science 76, $715-724$.
Leis, J.M., McCormick, M.I., 2002. The biology, behavior, and ecology of the pelagic, larval stage of coral reef fishes. In: Sale, P.F. (Ed.), Coral Reef Fishes: Dynamics and Diversity in a Complex Ecosystem. Academic Press, San Diego, pp. 171-199.

Leis, J.M., Miller, J.M., 1976. Offshore distributional patterns of Hawaiian fish larvae. Marine Biology 36, 359-367.

Leis, J.M., Stobutzki, C., 1999. Swimming performance of late pelagic larvae of coral-reef fishes: in situ and laboratory-based measurements. In: Séret, B., Sire, J.-Y. (Eds.), Proceedings of the Fifth Indo-Pacific Fish Conference, Nouméa, 1997. Societé Francaise d'Ichtyologie \& Institut de Recherche pour le Développement, Paris, pp. 575-583.

Lopes, P.C., Afonso, M.H., 1995. Ichthyoplankton abundance and larval diversity off the Portuguese continental coast. International Council for the Exploration of the Sea, 1-14 (C.M.1995/L:22, Ref. H).

Marliave, J.B., 1986. Lack of planktonic dispersal of rocky intertidal fish larvae. Transactions of the American Fisheries Society 115, 149-154.

Martins, F., Leitão, P., Neves, R., 2002. Simulating vertical water mixing in homogeneous estuaries: the Sado estuary case. Hydrobiologia 475/476, 221-227.

Martins, F., Leitão, P., Silva, A., Neves, R., 2001. 3D modelling in the Sado estuary using a new generic vertical discretization approach. Oceanologica Acta 24, 1-12.

Meekan, M.G., Milicich, M.J., Doherty, P.J., 1993. Larval production drives temporal patterns of larval supply and recruitment of a coral reef damselfish. Marine Ecology Progress Series 93, 217-225.

Milicich, M.J., Meekan, M.G., Doherty, P.J., 1992. Larval supply: a good predictor of recruitment of three species of reef fish (Pomacentridae). Marine Ecology Progress Series 86, 153-166.

Miller, J.A., Shanks, A.L., 2004. Evidence for limited larval dispersal in black rockfish (Sebastes melanops): implications for population structure and marine-reserve design. Canadian Journal of Aquatic Science 61, 17231735.

Miller, P.J., 1986. Gobiidae. In: Whitehead, P.J.P., Bauchot, M.-L., Hureau, J.-C., Nielsen, J., Tortonese, E.E. (Eds.), Fishes of the NorthEastern Atlantic and the Mediterranean. UNESCO, Paris, pp. 1019-1085.

Moita, M.T., Oliveira, P.B., Mendes, J.C., Palma, A.S., 2003. Distribution of chlorophyll $a$ and Gymnodinium catenatum associated with coastal upwelling plumes off central Portugal. Acta Oecologica 24, S125-S132.

Montgomery, J.C., Tolimieri, N., Haine, O., 2001. Active habitat selection by pre-settlement reef fishes. Fish and Fisheries 2, 261-277.

Moser, H.G., Richards, W.J., Cohen, D.M., Fahay, M.P., Kendall Jr. A.W., Richardson, S.L. (Eds.), 1984. Ontogeny and Systematics of Fishes. The American Society of Ichthyologists and Herpetologists. Allen Press, Lawrence, $759 \mathrm{pp}$.

Mora, C., Sale, P.F., 2002. Are populations of coral reef fish open or closed? Trends in Ecology \& Evolution 17, 422-428.

Myrberg Jr., A.A., Fuiman, L.A., 2002. The sensory world of coral reef fishes. In: Sale, P.F. (Ed.), Coral Reef Fishes: Dynamics and Diversity in a Complex Ecosystem. Academic Press, San Diego, pp. 123-148.

Neilson, J.D., Perry, R.I., 1990. Diel vertical migrations of marine fishes: an obligate or facultative process? Advances in Marine Biology 26, $115-168$.

Norcross, B.L., Shaw, R.F., 1984. Oceanic and estuarine transport of fish eggs and larvae: a review. Transactions of the American Fisheries Society 113, $153-165$

Olson, C.L., 1976. On choosing a test statistic in multivariate analysis of variance. Psychological Bulletin 83, 579-586.

Palomera, I., Olivar, M.P., 1996. Nearshore ichthyoplankton off the Costa Brava (northwest Mediterranean Sea). Publicaciones Especiales del Instituto Español del Oceanografía 22, 71-75.

Paris, C., Cowen, R.K., 2004. Direct evidence of a biophysical retention mechanism for coral reef fish larvae. Limnology and Oceanography 49, 1964-1979.

Pineda, J., 1994. Internal tidal bores in the nearshore: warm-water fronts, seaward gravity currents and the onshore transport of neustonic larvae. Journal of Marine Research 52, 427-458.

Pineda, J., 2000. Linking larval settlement to larval transport: assumptions, potentials and pitfalls. Oceanography of the Eastern Pacific 1, 84-105. 
Pitts, P.A., 1999. Effects of summer upwelling on the abundance and vertical distribution of fish and crustacean larvae of central Florida's Atlantic coast. Journal of Experimental Biology and Ecology 235, 135-146.

Planes, S., Galzin, R., Rubies, A.G., Goñi, R., Harmelin, J.-G., Le Diréach, L., Lenfant, P., Quetglas, A., 2000. Effects of marine protected areas on recruitment processes with special reference to Mediterranean littoral ecosystems. Environmental Conservation 27, 126-143.

Ré, P., 1999. Ictioplâncton Estuarino da Península Ibérica. Guia de Identificação dos Ovos e Estados Larvares Planctónicos. Câmara Municipal Cascais, Cascais, 163 pp.

Ré, P., Cabral e Silva, R., Cunha, M.E., Farinha, A., Meneses, I., Moita, T., 1990. Sardine spawning off Portugal. Boletim do Instituto Nacional de Investigação das Pescas 15, 31-44.

Riley, J.D., Symonds, D.J., Woolner, L.E., 1986. Determination of the distribution of the planktonic and small demersal stages of fish in the coastal waters of England, Wales and adjacent areas between 1970 and 1984. Fisheries Research Technical Report, MAFF Direct. Fisheries Research, Lowestoft 84, 23 pp.

Roughan, M., Mace, A.J., Largier, J.L., Morgan, S.G., Fisher, J.L., 2005a. Subsurface recirculation and larval retention in the lee of a small headland: a variation on the upwelling shadow theme. Journal of Geophysical Research Oceans 110 (C10027), 1-46.

Roughan, M., Terril, E.J., Largier, J.L., Otero, M.P., 2005b. Observations of divergence and upwelling around Point Loma, California. Journal of Geophysical Research Oceans 110 (C04011), 1-11.

Russell, F.S., 1973. A summary of the observations on the occurrence of planktonic stages off Plymouth 1924-1972. Journal of the Marine Biological Association of the United Kingdom 53, 347-355.

Russell, F.S., 1976. The Eggs and Planktonic Stages of British Marine Fishes. Academic Press, London, 524 pp.

Sabatés, A., Zabala, M., García-Rubies, A., 2003. Larval fish communities in the Medes Islands Marine Reserve (North-west Mediterranean). Journal of Plankton Research 25, 1035-1046.

Sale, P.F., 2004. Connectivity, recruitment variation and the structure of reef fish communities. Integrative Comparative Biology 44, 390-399.

Sampey, A., Meekan, M.G., Carleton, J.H., McKinnon, A.D., McCormick, M.I., 2004. Temporal patterns in distributions of tropical fish larvae on the North-west Shelf of Australia. Marine and Freshwater Research 55, 473-487.

Sanvicente-Añorve, L., Flores-Coto, C., Chiappa-Carrara, X., 2000. Temporal and spatial scales of ichthyoplankton distribution in the Southern Gulf of Mexico. Estuarine, Coastal and Shelf Science 51, 463-475.

Shanks, A.L., Grantham, B.A., Carr, M.H., 2003. Propagule dispersal distance and the size and spacing of marine reserves. Ecological Applications 13, $159-169$

Simpson, S.D., Meekan, M.G., McCauley, R., Jeffs, A., 2004. Attraction of settlement-stage coral reef fishes to reef noise. Marine Ecology Progress Series 276, 263-268.

Simpson, S.D., Meekan, M.G., Montgomery, J., McCauley, R., Jeffs, A., 2005. Homeward sound. Science 308, 221.
Sponaugle, S., Cowen, R.K., 1996. Nearshore patterns of coral reef fish larval supply to Barbados, West Indies. Marine Ecology Progress Series 133, 13-28.

Sponaugle, S., Cowen, R.K., 1997. Early life history traits and recruitment patterns of Caribbean wrasses (Labridae). Ecological Monographs 67, 177-202.

Sponaugle, S., Cowen, R.K., Shanks, A., Morgan, S.G., Leis, J.M., Pineda, J., Boehlert, G.W., Kingsford, M.J., Lindeman, K.C., Grimes, C., Munro, J.L., 2002. Predicting self-recruitment in marine populations: biophysical correlates and mechanisms. Bulletin of Marine Science 70, 341-375.

Sponaugle, S., Fortuna, J., Grorud, K., Lee, T., 2003. Dynamics of larval fish assemblages over a shallow coral reef in the Florida Keys. Marine Biology $143,175-189$.

Stobutzki, I.C., 2001. Marine reserves and the complexity of larval dispersal. Reviews in Fish Biology and Fisheries 10, 515-518.

Stobutzki, I.C., Bellwood, D.R., 1998. Nocturnal orientation to reefs by late pelagic stage coral reef fishes. Coral Reefs 17, 103-110.

Suthers, I.M., Frank, K.T., 1991. Comparative persistence of marine fish larvae from pelagic versus demersal eggs off southwestern Nova Scotia, Canada. Marine Biology 108, 175-184.

Swearer, S.E., Caselle, J.E., Lea, D.W., Warner, R.R., 1999. Larval retention and recruitment in an island population of a coral-reef fish. Nature 402, 799-802.

Swearer, S.E., Shima, J.S., Hellberg, M.E., Thorrold, S.R., Jones, G.P., Robertson, D.R., Morgan, S.G., Selkoe, K.A., Ruiz, G.M., Warner, R.R., 2002. Evidence of self-recruitment in demersal marine populations. Bulletin of Marine Science 70, 251-271.

Taylor, M.S., Hellberg, M.E., 2003. Genetic evidence for local retention of pelagic larvae in a Caribbean reef fish. Science 299, 107-109.

Tilney, R.L., Nelson, G., Radloff, S.E., Buxton, C.D., 1996. Ichthyoplankton distribution and dispersal in the Tsitsikamma National Park Marine Reserve, South Africa. South African Journal of Marine Science 17, 1-14.

Tolimieri, N., Haine, O., Jeffs, A., McCauley, R., Montgomery, J., 2004. Directional orientation of pomacentrid larvae to ambient reef sound. Coral Reefs 23, 184-191.

Tolimieri, N., Jeffs, A., Montgomery, J.C., 2000. Ambient sound as a cue for navigation by the pelagic larvae of reef fishes. Marine Ecology Progress Series 207, 219-224.

Tully, O., ÓCéidigh, P., 1989. The ichthyoneuston of Galway Bay (Ireland). Marine Biology 101, 27-41.

Valles, H., Sponaugle, S., Oxenford, H.A., 2001. Larval supply to a marine reserve and adjacent fished area in the Soufrière Marine Management Area, St Lucia, West Indies. Journal of Fish Biology 59 (Suppl. A), 152-177.

Victor, B.C., 1986. Larval settlement and juvenile mortality in a recruitmentlimited coral reef fish population. Ecological Monographs 56, 145-160.

Walker Jr., H.J., Watson, W., Barnett, A.M., 1987. Seasonal occurrence of larval fishes in the nearshore Southern California Bight off San Onofre, California. Estuarine, Coastal and Shelf Science 25, 91-109.

Warner, R.R., Cowen, R.K., 2002. Local retention of production in marine populations: evidence, mechanisms, and consequences. Bulletin of Marine Science 70, 245-249. 